\title{
Article \\ Integrated Energy Planning for Near-Zero Carbon Emission Demonstration District in Urban Areas: A Case Study of Meishan District in Ningbo, China
}

\author{
Xiaoyan $\mathrm{Xu}{ }^{1} \mathbb{D}$, Ying Wang ${ }^{2}$, Yingjun Ruan ${ }^{2, *}$, Jian Wang ${ }^{2, *}$, Kailiang Ge ${ }^{3}$, Yongming Zhang ${ }^{4}$ and Haikui Jin ${ }^{1}$ \\ 1 Tongji Architectural Design (Group) Co., Ltd., Shanghai 200092, China; 53xxy@tjad.cn (X.X.); \\ 53jhk@tjad.cn (H.J.) \\ 2 College of Mechanical and Energy Engineering, Tongji University, Shanghai 201804, China; 53wy@tjad.cn \\ 3 State Grid Ningbo Electric Power Supply Company, Ningbo 315016, China; gekl@163.com \\ 4 Sino-German College of Applied Sciences, Tongji University, Shanghai 201804, China; \\ zhangyongming@tongi.edu.cn \\ * Correspondence: ruanyj@tongji.edu.cn (Y.R.); wangjiantjad@tongji.edu.cn (J.W.); \\ Tel.: +86-021-6598-9750 (Y.R.); +86-021-3537-5002 (J.W.)
}

check for

Citation: Xu, X.; Wang, Y.; Ruan, Y.; Wang, J.; Ge, K.; Zhang, Y.; Jin, H. Integrated Energy Planning for Near-Zero Carbon Emission Demonstration District in Urban Areas: A Case Study of Meishan District in Ningbo, China. Energies 2022, 15, 874. https://doi.org/ 10.3390/en15030874

Academic Editors: Michal Cehlar and Sergey Zhironkin

Received: 29 November 2021

Accepted: 19 January 2022

Published: 25 January 2022

Publisher's Note: MDPI stays neutral with regard to jurisdictional claims in published maps and institutional affiliations.

Copyright: (C) 2022 by the authors. Licensee MDPI, Basel, Switzerland. This article is an open access article distributed under the terms and conditions of the Creative Commons Attribution (CC BY) license (https:// creativecommons.org/licenses/by/ $4.0 /)$.

\begin{abstract}
Reasonable regional integrated energy planning is an important prerequisite for the construction of a Near-Zero Carbon Emission Demonstration District (NCEDD). An integrated energy planning scheme that is based on a three-step planning method with the objective of achieving an NCEDD is proposed in this paper. First, the planning objectives should be determined. After that, the planning strategies should be established. Finally, the planning approaches should be proposed according to the previously determined objectives and strategies. A case study considering the integrated energy planning of the Meishan International Near-Zero Carbon Emission Demonstration District (MINCEDD) is investigated to explain the planning method. In addition, the planning results, which are indicated as indexes, are explained, analyzed, and compared to the ones of other districts. The indexes include a proportion of renewable energy to primary energy (73\% by 2030 and $108 \%$ by 2050), a proportion of renewable power to total power consumption ( $98 \%$ by 2030 and $111 \%$ by 2050), and $\mathrm{CO}_{2}$ emission reduction rates $(70 \%$ by 2030 and $100 \%$ by 2050) and are more advanced than other districts in China. This planning scheme and method can provide a reference for the integrated energy planning of NCEDDs in developed urban areas.
\end{abstract}

Keywords: integrated energy planning; near-zero carbon emission; near-zero carbon emission demonstration district; renewable energy; urban district planning methods

\section{Introduction}

Strategic objectives were proposed during the 2015 United Nations Climate Conference in Paris which aimed to control the average global temperature within $2^{\circ} \mathrm{C}$ of pre-industrial levels and make substantial effort to control temperature increases within $1.5^{\circ} \mathrm{C}$ to achieve a peak of global greenhouse gas emissions (GHGs) as soon as possible, and achieve net-zero GHGs during the second half of this century [1].

Therefore, a series of policies have been proposed by countries to achieve carbon neutrality by 2050. For example, the European Union (EU) proposed that it would be carbon neutral by 2050 and hence released "The European Green Deal" in 2019 during the United Nations Climate Change Conference, which details key policies and core technologies in essential areas that are to be developed and the release of eight major goals [1,2]. The U.S. House of Representatives published "The Congressional Action Plan for a Clean Energy Economy and a Healthy, Resilient, and Just America" to promote the U.S. to achieve net-zero carbon emissions by 2050 [3]. Japan issued "The Green Growth Strategy", which introduced the country's goal to be carbon neutral by 2050 and proposed specific development goals and essential development tasks for core industries [4]. 
In order to contribute to the net-zero GHGs, China announced that peak $\mathrm{CO}_{2}$ emissions will be achieved by 2030 and that the nation will become as carbon neutral as possible by 2060 [5]. Additionally, tens of Chinese policies related to the reduction in carbon emissions, renewable energy, the electricity market, energy storage, etc., have been promulgated by various management departments from 2020 to 2021. One of these policies is called "Opinions of the Central Committee and the State Council on the complete, accurate and comprehensive implementation of the new development concept to achieve carbon peaking and carbon neutral". The importance of energy planning is stressed by this policy. It is indicated that the carbon-neutral district is reaching the carbon emission limit rather than completely zero carbon emission. In the meantime, the requirements for both the supply and demand sides, as well as for multiple fields, such as energy, construction, industry, and transportation, need to be coordinated and put forward to achieve carbon neutrality [6]. Moreover, the Top Ten Actions for Carbon Peaking were announced in another Chinese policy called the "Carbon Peaking Action Plan by 2030", which aim to promote peak carbon emissions by 2030 [7].

Cities and provinces in China are projected to reach peak $\mathrm{CO}_{2}$ emission between 2020 and 2030, while some relatively developed cities, such as Beijing, Zhenjiang, Shenzhen, etc., were projected to reach peak $\mathrm{CO}_{2}$ emissions before 2020 [8].

The definition of $\mathrm{CO}_{2}$ emission is clarified by IPCC and is defined is the sum of the GHGs that are converted into equivalent $\mathrm{CO}_{2}$ emissions by the indexes of global warming potential (GWP), global temperature potential (GTP), radiative forcing equivalence potential, etc. [9]. However, there are various definitions of $\mathrm{CO}_{2}$ emissions when defining emission targets related to carbon neutrality among countries [10]. In most western and in Asian countries, such as Demark, Slovakia, Chile, Switzerland, Portugal, Canada, the United Kingdom (UK), Singapore, Germany, Sweden, France, Finland, Japan, etc., $\mathrm{CO}_{2}$ emissions are defined as GHGs. $\mathrm{CO}_{2}, \mathrm{CH}_{4}$, and $\mathrm{N}_{2} \mathrm{O}$ emissions are defined as $\mathrm{CO}_{2}$ emissions in Bhutan and Uruguay. However, the definition in China and in many other countries is not clear. In this paper, $\mathrm{CO}_{2}$ emissions refer to the GHGs in equivalent amounts of $\mathrm{CO}_{2}$ based on GWP, including the emissions from fossil fuel combustions caused by transportation, electricity generation, manufacturing, building operations, etc.

Cai et al. [11] indicate that increases in carbon emissions are mainly driven by the population. In addition, over $90 \%$ of the total $\mathrm{CO}_{2}$ emission in China are from urban areas [8]. This means that reducing $\mathrm{CO}_{2}$ emissions in urban areas is significant for the total carbon reduction in the entire country, and conducting near-zero carbon emission programs is one of the current strategies in China that is being implemented to reduce carbon emissions in urban areas.

The Near-Zero Carbon Emission Demonstration District (NCEDD) project was first proposed in the China's 13th Five-Year Plan. This project is one of the 12 projects of the 13th Five-Year Plan and has caused widespread concern in the community. Moreover, the 13th Five-Year Plan proposed that GHG control measures in mature areas, which are subject to restricted and prohibited development, ecological functional areas, industrial mining areas and towns, etc., should be selected to carry out the NCEDD project and that 50 demonstration projects should be built by 2020 .

In order to carry out the NCEDD, researchers, such as the IPCC, have mainly discussed near-zero carbon emissions in terms of its connotations. The IPCC indicates that carbon neutrality or net-zero $\mathrm{CO}_{2}$ emissions are achieved when annual $\mathrm{CO}_{2}$ emissions are considered to be balanced by decarburization technologies [9]. Near-zero carbon emissions are defined as being achieved when the net carbon emissions are approaching zero in a specific area. The relationship among near-zero carbon emissions, low carbon emissions, and zero carbon emissions is shown in Figure 1. Zero carbon emissions is the final objective for low-carbon community construction, while low carbon emissions and zero carbon emissions are necessary in the process to achieve zero carbon emissions. The net carbon emissions of a specific district can be decreased to zero gradually by reducing carbon 
emissions from the supply, contributing to zero carbon energy, etc. Moreover, near-zero carbon emissions refer to contexts that are approaching zero carbon emission situations.

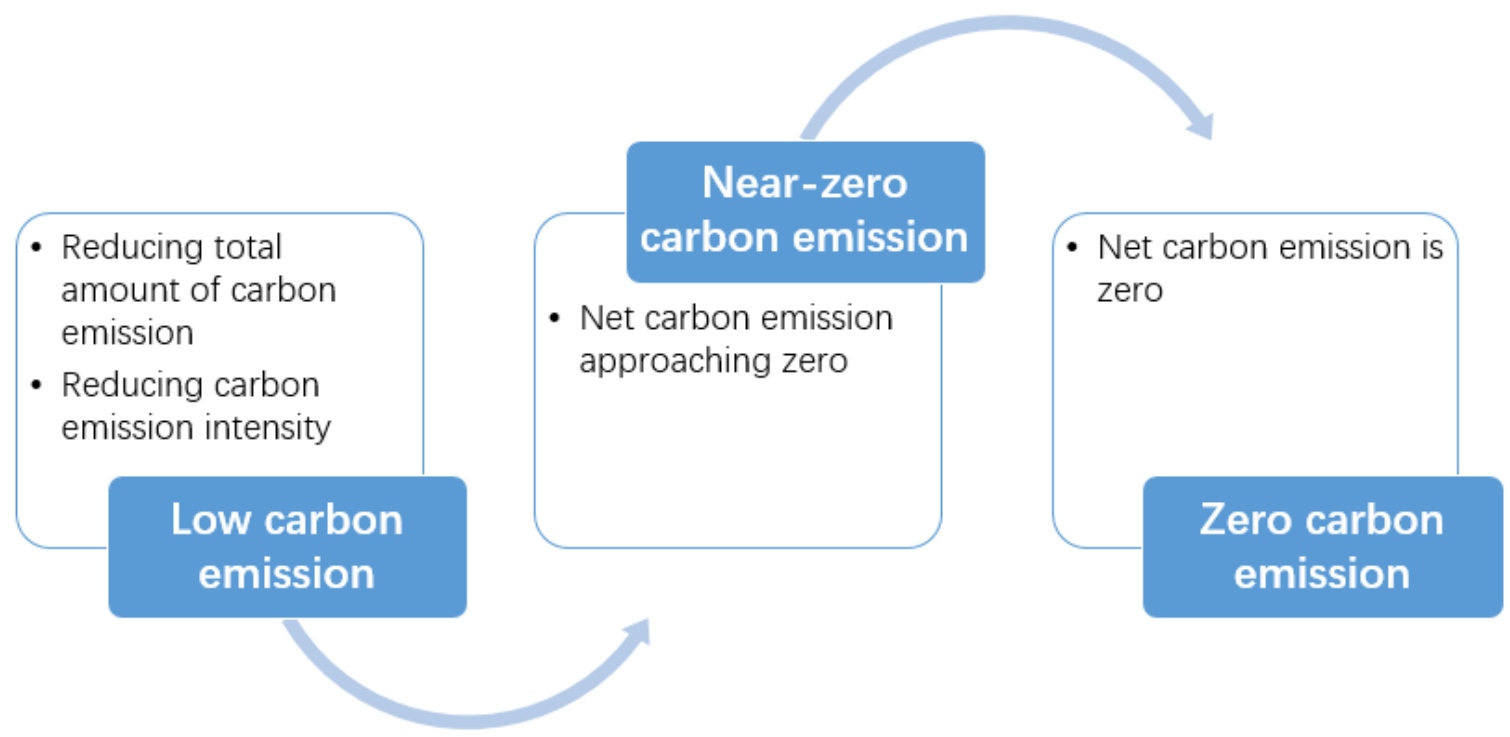

Figure 1. The relationship among near-zero carbon emissions, low carbon emissions, and zero carbon emissions.

The definition of an NCEDD can be explained based on the meaning of near-zero carbon emissions. Demonstration districts represent typical districts that are developed and constructed in advance. The development mode can play a demonstration role, and the experience can be replicated and promoted. Li et al. [12] define NCEDDs with near-zero carbon emission as follows: A typical district where the objective net carbon emissions approaching zero is achieved using approaches that reduce source carbon emissions, increase carbon sequestration, or contribute zero carbon energy, etc., within the boundaries of the county's (county-level city/district) administrative divisions and where the carbon-emission-reducing methods are replicable and can be promoted. Furthermore, two quantitative indexes are proposed for NCEDDs and are as follows: (1) It is possible for the total net carbon emissions to reach levels closer to zero by offsetting source carbon emissions and carbon sequestration or by offsetting source carbon emissions and by contributing zero carbon energy; (2) absolute carbon emissions reach their peak value. These quantitative indexes are also important integrated energy planning objectives for NCEDDs.

Liu [13] concludes four types of NCEDDs. The first type is 100\% renewable energy demonstration districts, which are applicable to less developed areas with plentiful renewable energy resources. The second type is carbon-neutral demonstration districts, which are applicable for scenic areas with large amounts of forests and pastoral areas. The third type of NCEDD is partial demonstration in the industry, for example, near-zero carbon emission buildings. The fourth type of NCEDD is low carbon emission upgrades, which is further decarburized on the basis of current low carbon emission pilot projects. The first and second types are constrained by regional and resource issues, and they are not able to be promoted in developed urban areas. The third and fourth types only consider near-zero carbon emissions in a narrow sense. It is necessary to determine how to build NCEDDs in developed urban areas.

Reasonable district-integrated energy planning is an important part of constructing urban NCEDDs. Recently, the commonly used methods for energy planning are demandside energy planning and supply-side energy planning. In Chinese urban planning systems, urban power planning, gas planning, and centralized cooling and heating planning mostly belong to supply-side energy planning, i.e., top-down planning. However, demand-side energy planning starts from the demand side, pays attention to the effective integration 
and reasonable application of various energy resources in urban areas, and is a bottom-up process. In recent years, demand-side energy planning has been utilized more and more often in district-integrated energy planning.

Recently, there has been increasing amounts of research into demand-side planning, a large amount of which has been conducted by Long [14-17], Jelić [18], Wang [19], and $\mathrm{Yu}[20]$ et al. Most of these researches proposed reducing energy demand, utilizing renewable energy sources instead of fossil fuels, and capturing and storing carbon (CCS). These are solutions also indicated by Khalilpour [21] as specific technical approaches for the reduction in carbon emissions. However, developed urban areas lack carbon sequestration resources, such as forests and pastoral areas, which makes it even more difficult for them to achieve near-zero carbon emissions. Apart from reducing energy demand and applying renewable energy, Dobbelsteen et al. [22] proposed seeking energy synergy rather than CCS in urban energy planning. In addition, energy cascade utilization, the reuse of waste heating, energy storage, etc., are ways in which energy synergy can be implemented, which can provide heating and cooling network connections at different temperature levels.

In existing research, there is generally no clear planning method for district energy planning and few implementation conditions for energy schemes [23-27]. There have been numerous limitations in the research that has been carried out recently. The Shenzhen Academy of Building Research Co., Ltd. [23] conducted a green and ecological district in Ya'an by energy demand forecasting and energy resources analysis. The renewable energy and heat pump systems are planned to take place after evaluation. Cheng et al. [24] proposed four available energy station schemes with integrated energy utilization and energy micro-grid in a northern district. Tang et al. [25] developed energy schemes for a district in Guilin by determining planning objectives and analyzing energy demand and energy resources. The Tianjin Architectural Design Institute et al. [26] utilized a planning method that consisted of project investigation, demand forecasting, the proposal of energy schemes, the evaluation and comparison of energy schemes, and the determination of recommended schemes. The energy schemes for the university park in Tianjin were proposed and determined by the HVAC, electrical, water supply, and drainage energy consumption sectors. Although this method is relatively clear, it is only suitable for building sector districts rather than industrial and traffic sectors. Zhejiang Zheneng Energy Service Co., Ltd. et al. [27] proposed an integrated energy planning scheme for a district called Xiangbao in Ningbo. The distributed energy stations are planned for buildings and industries. Additionally, special planning for solar energy, electricity, water source, and utility tunnels is proposed based on local conditions. However, there are limitations for the above researches in terms of the absence of clear planning methods, planning objectives, and integrated and implementable energy schemes. The limitations of the above mentioned researches are listed in Table 1.

Table 1. The limitations of recent research into district energy planning.

\begin{tabular}{|c|c|c|c|c|c|}
\hline Planned District & Ya'an & $\begin{array}{l}\text { A Northern } \\
\text { District }\end{array}$ & Guilin & Tianjin & Xiaongbao \\
\hline Absence of clear planning method & $\bullet$ & • & $\bullet$ & $\bullet$ & $\mathrm{N} / \mathrm{A}$ \\
\hline Absence of planning objectives & $\bullet$ & $\bullet$ & $\mathrm{N} / \mathrm{A}$ & $\bullet$ & $\bullet$ \\
\hline Absence of demand reducing schemes & $\bullet$ & $\bullet$ & $\bullet$ & $\bullet$ & $\bullet$ \\
\hline $\begin{array}{l}\text { Absence of quantitative analysis, layout, and } \\
\text { application scenarios of energy schemes }\end{array}$ & • & • & • & $\mathrm{N} / \mathrm{A}$ & $\mathrm{N} / \mathrm{A}$ \\
\hline Absence of renewable energy utilzation schemes & $\mathrm{N} / \mathrm{A}$ & $\mathrm{N} / \mathrm{A}$ & $\mathrm{N} / \mathrm{A}$ & $\bullet$ & $\mathrm{N} / \mathrm{A}$ \\
\hline Absence of grid or storage schemes & $\bullet$ & $\mathrm{N} / \mathrm{A}$ & $\bullet$ & $\bullet$ & $\mathrm{N} / \mathrm{A}$ \\
\hline
\end{tabular}

"•" means the condition that is invloved in the district planning.

In this paper, a case study of the Meishan International Near-Zero Carbon Emission Demonstration District (MINCEDD) was investigated in order to propose an integrated energy planning scheme for this district. Moreover, a three-step planning method for the planning of NCEDDs was proposed and includes planning objectives, approaches, and 
strategies. After that, the planning results were analyzed and compared with respect to the indexes of renewable energy and $\mathrm{CO}_{2}$ reduction.

\section{Methods and Algorithms}

\subsection{The Three-Step Planning Method}

A three-step planning method for NCEDD development is proposed that determines the planning objectives, planning strategies, and planning approaches. Firstly, the planning objectives are determined by focusing on targets such as $\mathrm{CO}_{2}$ reduction, renewable energy utilization, etc. After that, the planning strategies are formed as the overall principles of the planning approaches, which consist of reducing energy demand, applying renewable energy based on local resource conditions, and improving integrated energy efficiency through means such as thoroughly utilizing waste heat on the demand side. Finally, the planning approaches are proposed based on the objectives and on the local conditions affecting access to natural resources, current and planned building construction, traffic and industry, etc., and can be categorized into the demand-side, supply-side, grid-side, and storage-side approaches, according to the energy application segment.

\subsubsection{Determining the Planning Objectives}

The objectives should be determined to satisfy the NCEDD target as well as to be appropriate the local conditions of the district. Therefore, the research team investigated local energy supply companies, local governments, local factories, etc. to thoroughly understand the current conditions for renewable energy utilization and potential, the electricity supply, industrial energy consumption, and waste energy potential, etc.

The research team evaluated and researched the energy utilization potential and advantage of the district by analyzing the current energy supply, energy consumption, and renewable and waste energy potential. After that, the NCEDD objectives were determined with respect to the indexes of renewable energy utilization and $\mathrm{CO}_{2}$ emission reduction.

\subsubsection{Establishing the Planning Strategies}

In order to the achieve the objectives that were previously determined, the planning strategies were established from the aspects of reducing energy demand, improving energy efficiency, and utilizing both waste heat and renewable energy. The strategies must not only be established according to the objectives but should also be adapted to the local conditions of the planned district.

\subsubsection{Proposing the Planning Approaches}

Planning approaches are based on "demand-supply-grid-storage", which means reducing energy demand on the demand side, utilizing renewable energy on the supply side, and improving energy interconnection and peak load shifting on the grid and storage sides so as to achieve the objectives of the MINCEDD.

\subsection{The Calculation Algorithms of Planning Indexes}

After applying the three-step planning method, including the objectives, strategies, and approaches, indexes with respect to renewable energy utilization and $\mathrm{CO}_{2}$ emission reduction are proposed and summarized in Table 2. The indexes were evaluated by analyzing and comparing other similar planned districts. The advancement and feasibility of the planning scheme based on the three-step planning method can be proven after the evaluation.

\subsubsection{Proportion of Renewable Energy to Primary Energy}

In order to explain the definition of the RE/PE index, the algorithm of this index is introduced followed by its explanation in this sub-section.

Algorithm: Total renewable energy consumption (tce) $\div$ Total primary energy consumption (tce) $\times 100 \%$ 
Table 2. The summary of major planning indexes.

\begin{tabular}{ccccc}
\hline Indexes & $\begin{array}{c}\text { Objectives of } \\
\mathbf{2 0 3 0}\end{array}$ & $\begin{array}{c}\text { Planning Results } \\
\text { of 2030 }\end{array}$ & $\begin{array}{c}\text { Objectives of } \\
\mathbf{2 0 5 0}\end{array}$ & $\begin{array}{c}\text { Planning Results } \\
\text { of 2050 }\end{array}$ \\
\hline $\begin{array}{c}\text { Proportion of renewable energy to primary } \\
\text { energy (RE/PE) }\end{array}$ & $\geq 70 \%$ & $73 \%$ & $\geq 90 \%$ & $108 \%$ \\
$\begin{array}{c}\text { Proportion of renewable power to total } \\
\text { power consumption (RP/PC) }\end{array}$ & $\geq 90 \%$ & $98 \%$ & $100 \%$ & $111 \%$ \\
$\mathrm{CO}_{2}$ emission reduction (ton) & $\geq 750,000$ & 780,000 & $\geq 1,100,000$ & $1,210,000$ \\
$\mathrm{CO}_{2}$ emission reduction rate & - & $70 \%$ & - & $100 \%$ \\
\hline
\end{tabular}

Explanation: Renewable energy refers to the energy rather than fossil fuels and includes wind energy, solar energy, water energy, biomass, geothermal energy, ocean energy, etc. According to the second provision of the "China National Renewable Energy Law" [28], renewable energy power mainly consists of solar PV, wind power, biomass power, etc. Primary energy refers to the energy resources that exist in nature without processing and conversion, also known as natural energy, such as coal, oil, natural gas, hydropower, etc.

Total energy consumption is the total amount of annual energy consumed on the demand side in the planned district. RE/PE is the amount of total annual consumed renewable energy divided by the total annual consumed primary energy in the planned district.

\subsubsection{Proportion of Renewable Power to Total Power Consumption}

In order to explain the definition of the RP/PC index, the algorithm for this index is introduced followed by its explanation in this sub-section.

Algorithm: Renewable energy power generation $(\mathrm{kWh}) \div$ District total power consumption $(\mathrm{kWh}) \times 100 \%$

Explanation: Power generation refers to energy generation on the supply side. The meaning of renewable power is the power generated from the renewable energy that is explained in Section 2.2.1. RP/PC is the total annual renewable power generated divided by the total annual power consumed in the planned district.

\subsection{3. $\mathrm{CO}_{2}$ Emission Reduction}

In order to explain the definition of the $\mathrm{CO}_{2}$ emission reduction index, the algorithm of this index is introduced followed by its explanation in this sub-section.

Algorithm: $\left(\mathrm{CO}_{2}\right.$ emission caused by conventional energy supply $-\mathrm{CO}_{2}$ emission caused by near-zero carbon emission energy supply) $\div \mathrm{CO}_{2}$ emission caused by conventional energy supply $\times 100 \%$

Explanation: Conventional energy is the primary energy that has been mass-produced and widely used, such as coal, oil, natural gas, etc. Zero-carbon emission energy is the energy that is generated and consumed without creating carbon emissions, such as solar energy, wind energy, ocean energy, geothermal energy, etc. The near-zero carbon emission energy supply refers to the combination of conventional and zero-carbon emission energy supply in planned districts, which leads to the overall near-zero carbon emission effect.

The three-step planning method process is shown in Figure 2. 


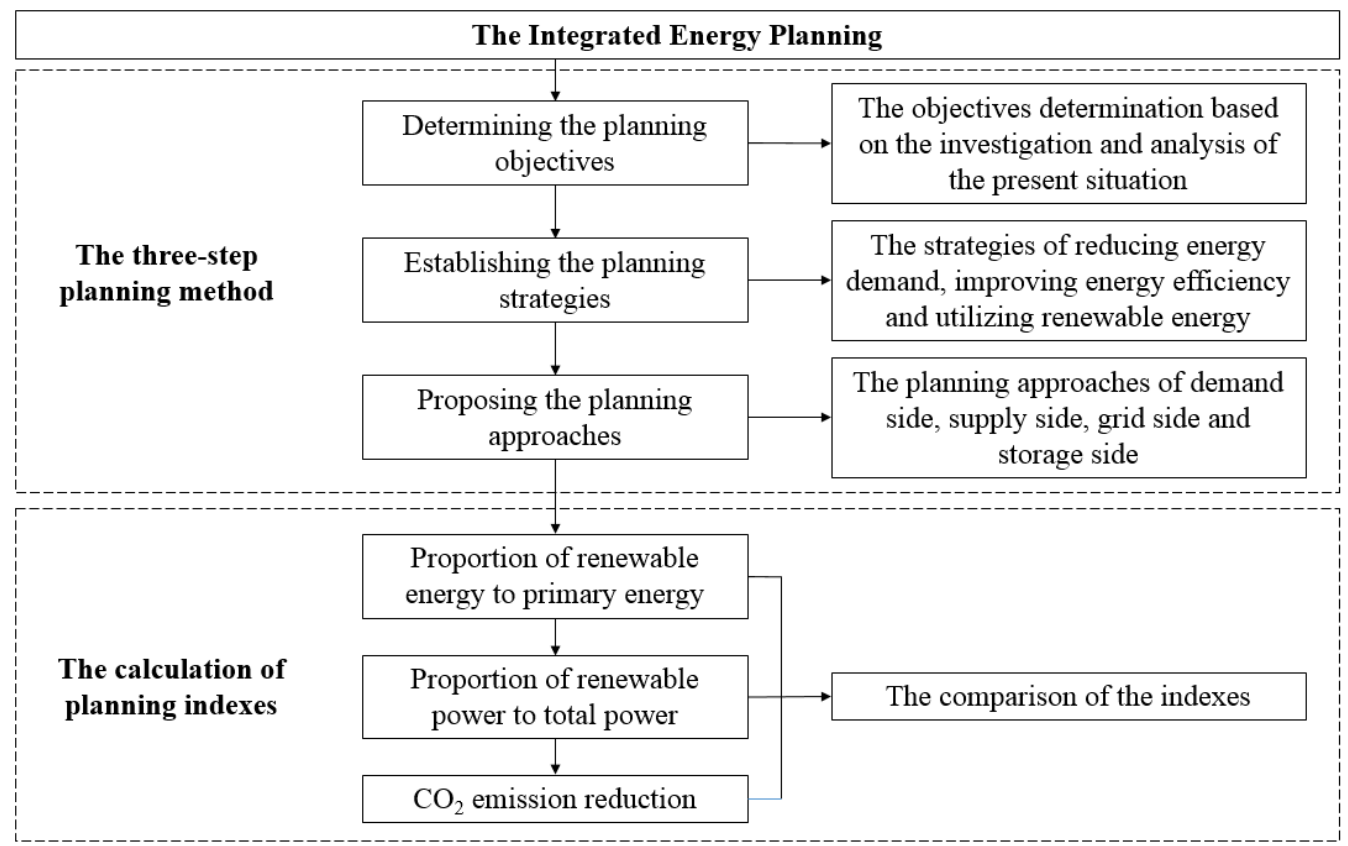

Figure 2. The three-step planning method process.

\section{Present Situation of the Planning District}

\subsection{The Planning Area and Planning Period}

The MINCEDD planning area, which is located in Ningbo, Zhejiang province, is $333 \mathrm{~km}^{2}$ and includes Meishan Island in the Beilun area, Chunxiao Street, and Baifeng Town. The planning area is shown in Figure 3.

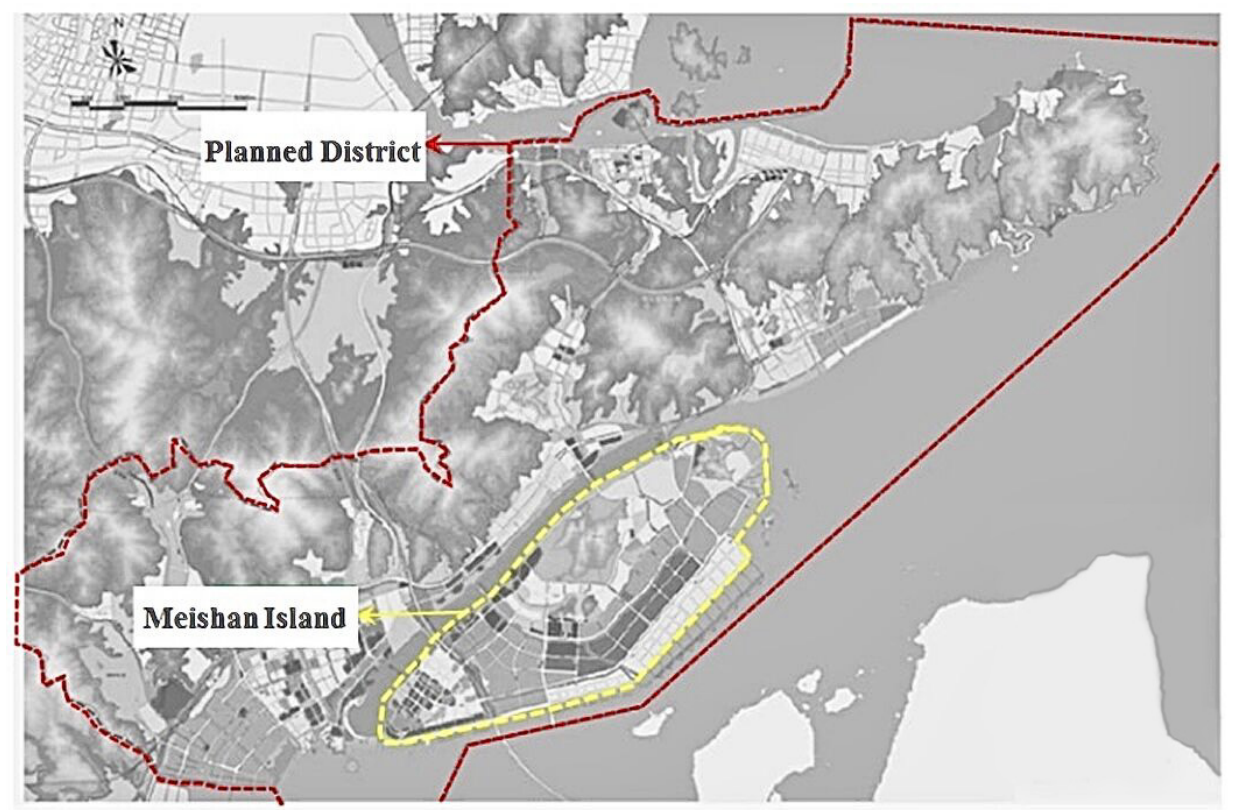

Figure 3. The MINCEDD planning area.

According to the regulatory plans, the main planning area comprises six core areas that make up a total land area of $43.49 \mathrm{~km}^{2}$ and includes Financial Town, the Menhu Area, the Industry Area, the Bonded Area, the East Area, and the Li'ao Area (as is shown in Figure 4). 


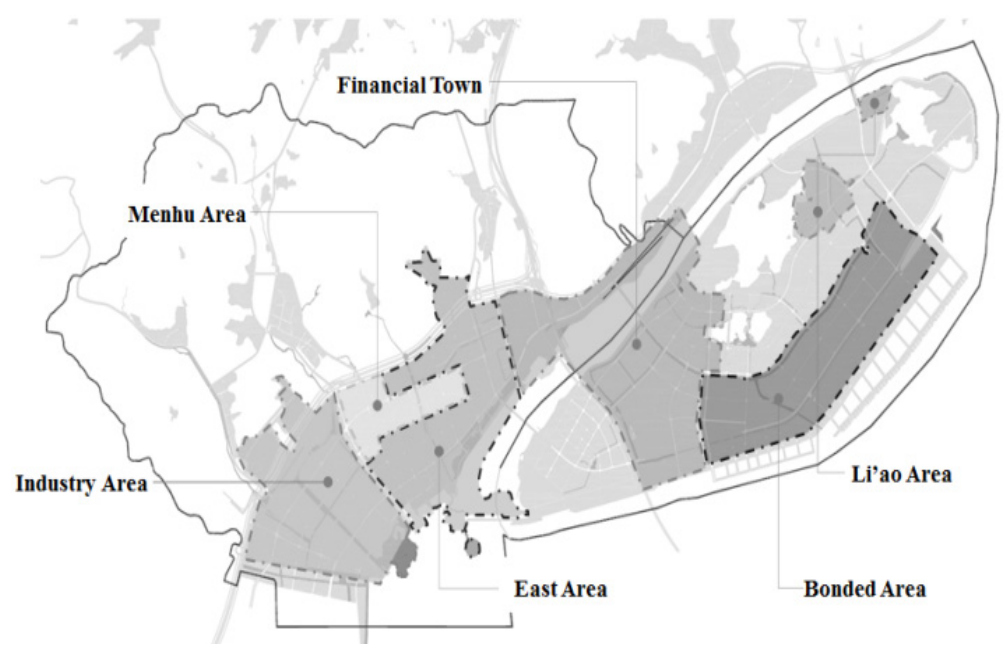

Figure 4. The planning areas.

The planning period is from 2020 to 2050, with mid-term planning taking place from 2020 to 2030 and long-term planning taking place from 2030 to 2050.

\subsection{Local Energy Resources}

The MINCEDD belongs to the subtropical monsoon climate zone (see Figure 5) [29] and contains abundant renewable resources and clean energy. In order to appropriately propose energy planning schemes based on local conditions, energy resources, including solar energy, wind energy, biomass energy, liquefied natural gas (LNG) cold energy, and hydrogen energy, are each analyzed and evaluated in the following.

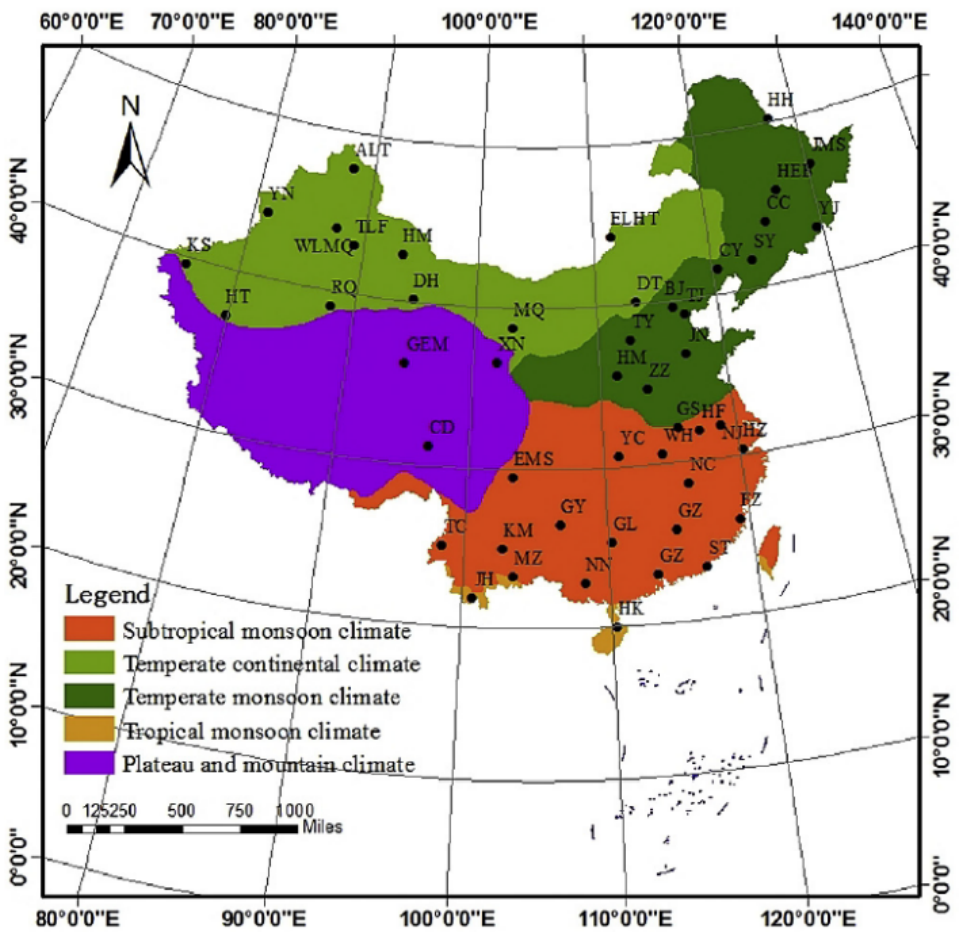

Figure 5. Climate zone distribution of China.

\subsubsection{Solar Resource}

Solar energy is one of the most competitive sources of renewable energy due to its abundance and clean operation. Total annual solar radiation of MINCEDD is greater than $4008 \mathrm{MJ} / \mathrm{m}^{2} / \mathrm{a}[30]$. 


\subsubsection{Wind Resource}

Wind resources are relatively rich in the MINCEDD [31]. Wind resources are simulated using computational fluid dynamics (CFD) numerical software. The simulation results show that in the winter and summer, the dominant wind directions are northwest and southeast, respectively. In addition, the dominant wind speed is about $7.48 \mathrm{~m} / \mathrm{s}$ in winter and $7.95 \mathrm{~m} / \mathrm{s}$ in summer and occurs at the height of $80 \mathrm{~m}$. The wind speed distribution map at different heights in the planning area is shown in Figure 6.

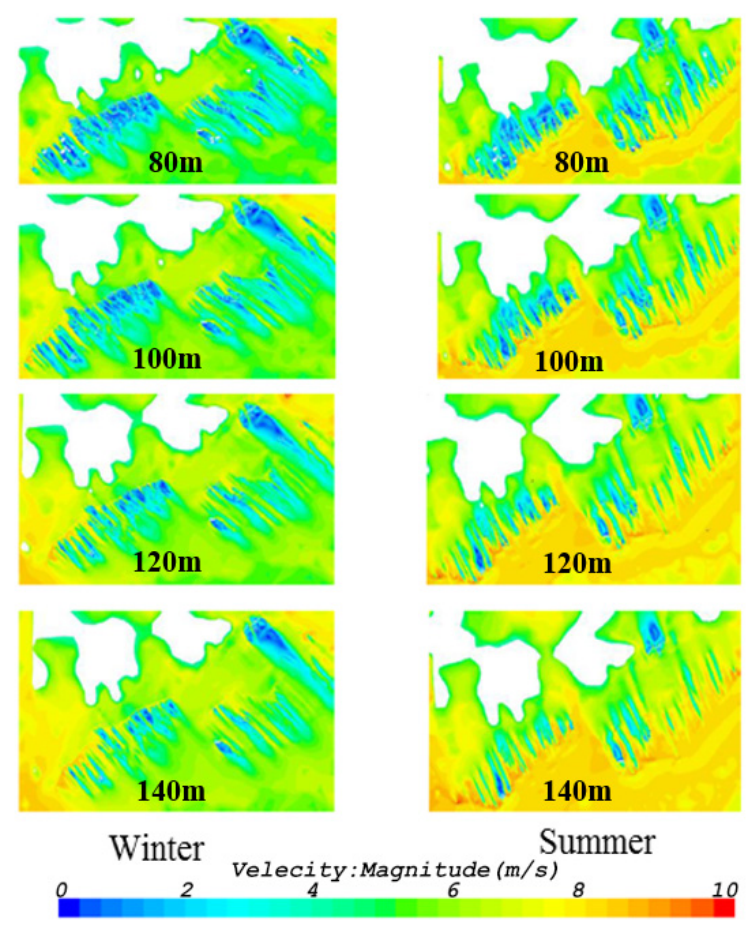

Figure 6. Wind speed chart at different heights.

\subsubsection{Hydrogen Energy Resource}

Ningbo is a city with a large amount of industrial by-product hydrogen, which is mostly expulsed from the Daxie Industrial Park. According to TrendBank statistics, Ningbo can supply about $72 \mathrm{kt} / \mathrm{yr}$ of by-product hydrogen, which indicates the large planning potential of by-product hydrogen from the industry sector. Moreover, the purity of industrial by-product hydrogen from Donghua Energy and from Wanhua Chlor-Alkali is $99.99 \%$ based on site investigations. Existing hydrogen by-product production is detailed in Table 3.

Table 3. Industrial by-product hydrogen in Ningbo area.

\begin{tabular}{cc}
\hline Company Name & $\begin{array}{c}\text { Hydrogen Production } \\
\text { (ton/a) }\end{array}$ \\
\hline Zhenhai Refinery & 144,000 \\
Sinochem & 117,000 \\
Zhenyang Chemical Industry & 8100 \\
Siming Chemical & 7200 \\
Beilun Area & 9400 \\
Daxie Petrochemical & 53,000 \\
Wanhua Chemical & 70,000 \\
Wanhua Chlor-Alkali & 15,000 \\
Donghua Energy & 20,000 \\
Total & 443,700 \\
\hline
\end{tabular}




\subsubsection{LNG Cold Energy Resource}

An LNG receiving station that belongs to Zhonghai Ningbo Liquefied Natural Gas Co., Ltd. is located at the northeast end of the planning area. The external transmission capacity of the LNG receiving station is 7 million tons per year. Currently, only 400 ktons of LNG per year is used for cold energy air separation operations, while most of the remaining cold energy is released into the sea water. Hence, there is large application potential in which the remaining cold energy can be used. The LNG receiving station location is shown in Figure 7.

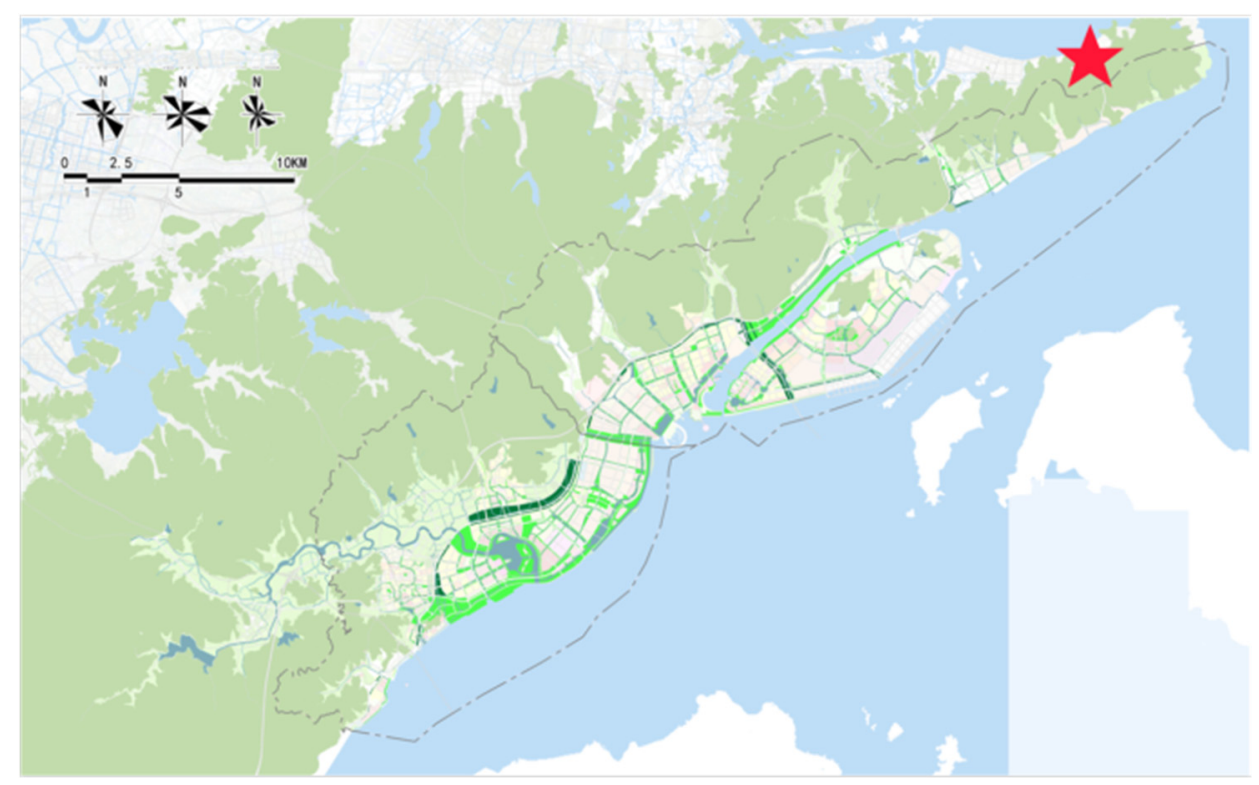

Figure 7. Geographical location of the LNG receiving station.

\subsubsection{Other Resources}

The biomass resources and low-grade heat sources in the planning area were investigated and evaluated. The existing biomass power plants cover all biomass resources in the planned district and part of the biomass resources beyond the MINCEDD in Ningbo (including domestic waste). There is additional capacity that can be used by the MINCEDD biomass power plant in the future even though the capacity of the plant will maintain its status due to garbage odor concerns in the selected location. In addition, a sewage treatment plant with a daily treatment capacity of 35,000 tons will be built in the near future. According to the progress being made in the construction of the sewage plant and the surrounding users, it is proposed that a small-scale sewage source heat pump system can be developed by the MINCEDD in the future. Apart from biomass and sewage source, low-grade heat sources, groundwater sources, soil sources, and seawater sources are not suitable for exploitation due to the environmental and policy constraints.

\subsection{Current Energy Consumption}

The total energy consumption in the MINCEDD was about 318 ktce in 2017 and includes 106.9 ktce of building consumption, 177.3 ktce of industry consumption, and 34.2 ktce of traffic consumption. The building, industry, and traffic sectors account for $33.5 \%, 55.7 \%$, and $10.8 \%$ of the total energy consumption, respectively.

In addition, there are 235.8 ktce of primary energy that are consumed by electricity, which is $74.1 \%$ of the total primary energy consumption. The natural gas consumption is $27.5 \mathrm{ktce}$ and fossil fuel (incl. coal and oil) consumption is $55 \mathrm{ktce}$, representing $8.6 \%$ and $17.3 \%$ of total primary energy, respectively. Figure 8 illustrates the energy consumption and percentages of different energy sectors and energy sources [32]. 


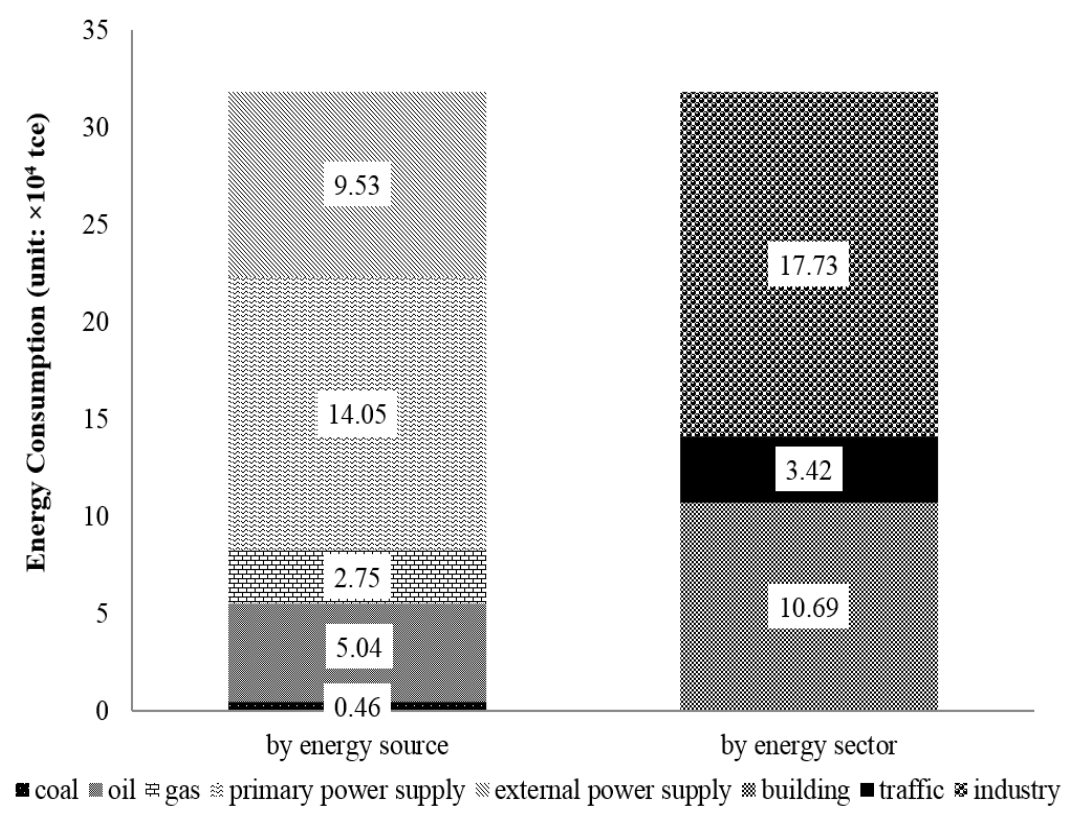

Figure 8. The composition of primary energy consumption.

\section{The Integrated Energy Planning Scheme}

\subsection{The Planning Objectives}

The primary energy consumption is 318 ktce in 2017, and the energy intensity per unit GDP is 0.15 tce/CNY. The integrated energy planning objectives for the MINCEDD were determined by taking NCEDD as a guide, planning based on the local population and GDP, integrating local energy resources and energy demand characteristics, and using the quantitative scenario analysis method [33]. The planning objectives are listed in Table 4.

Table 4. The planning objectives and index compliance.

\begin{tabular}{ccc}
\hline Indexes & Objectives of 2030 & Objectives of 2050 \\
\hline $\mathrm{RE} / \mathrm{PE}$ & $\geq 70 \%$ & $\geq 90 \%$ \\
$\mathrm{RP} / \mathrm{PC}$ & $\geq 90 \%$ & $100 \%$ \\
$\mathrm{CO}_{2}$ emission reduction (ton) & $\geq 750,000$ & $\geq 1,100,000$ \\
\hline
\end{tabular}

\subsection{The Planning Strategies}

\subsubsection{Reducing Energy Demand}

The core of achieving the objective of near-zero carbon emissions is reducing energy consumption on the demand side and increasing the sources of the energy supply. Energy demands consist of building demand, industry demand, and traffic demand.

Building demand can be reduced by passive measures, which are as follows: (1) improving building envelope performance to reduce winter heating and summer cooling and (2) introducing natural ventilation to reduce the demand for cooling and heating during the transition seasons.

Industry demand can be reduced by industrial restructuring, which is achieved by restricting and gradually eliminating high-energy-demand industries (i.e., energy consumption per unit output value higher than $0.07 \mathrm{kgce} / \mathrm{CNY}$ ) and introducing high output with low-energy-consumption industries (i.e., energy consumption per unit output value lower than $0.015 \mathrm{kgce} / \mathrm{CNY}$ ).

Traffic demand is reduced by transportation energy transformation and by changing the travel mode, for instance, restricting cars with high emissions, encouraging public and green travel, etc. 


\subsubsection{Improving Energy Efficiency and Utilizing Waste Heat}

1. Improving energy efficiency of building sector:

In buildings, energy consumption mainly takes place through lighting, sockets, air conditioning, power system, and special equipment.

In terms of lighting, a building's energy consumption can be reduced by using LED lights, installing intelligent control, controlling the lighting by zones, etc.

The amount of energy consumed by a building in terms of air conditioning can be reduced by improving the energy efficiency of a system and equipment, such as heating/cooling units, boilers, pumps, fans, air handling units, etc.

The amount of energy that a building consumes in terms of its power system consists of the energy that is used by water pumps, elevators, etc. The energy efficiency measures for water pumps refers to the selection of high-efficiency and variable-frequency equipment. The energy efficiency measures for elevators are variable frequency, group controlling, etc.

Waste heat can be applied in the following ways. (1) Heat recovery on the air system side: Using a heat exchanger to recover the heat from exhaust air or fresh air so that the fresh air can be pre-heated or cooled and can reduce the energy for fresh air. (2) Units can recover condensation heat: The heat that is generated from cooling condensation water in the summer is recovered for domestic hot water heating to decrease the hot water heating energy, which has a significant energy-saving effect for buildings with a high demand for domestic hot water such as in-patient buildings and hotels. (3) Elevator energy feedback: The energy that is generated during elevator operation is given back to the power grid or to the micro power grid for reuse, which can save electricity consumption by about $30 \%$.

2. Improving energy efficiency of industry sector:

First, the energy efficiencies of general equipment, such as boilers, motors, transformers, and air compressors, should be improved.

Second, heat recovery and cascade utilization are the major approaches for reusing industrial waste heat. This means the recovered heat is used for industrial processes or for heating the areas in the building. Most equipment, such as prime motors, heating furnaces, air compressors, annealing furnaces, VOC handling units, boilers, etc., only consume small amounts of heating energy. Recovering the remaining industrial heating energy for centralized heating can save primary energy, improve economic benefit, and reduce pollution.

\subsubsection{Utilizing Renewable Energy Adapted to Local Conditions}

For urban areas, utilizing renewable energy that can be adapted to local conditions is the last guaranteed method through which near-zero carbon emissions can be achieved and is based on decreasing energy demand, improving energy efficiency, and using waste heat. This means providing zero-carbon emission energy supply, which is close to or is more than fossil fuel consumption.

Renewable energy consists of solar energy, wind energy, ocean energy, geothermal energy, etc. Distributed renewable energy is the best way to use renewable energy sources. This can be achieved, for example, by installing a solar photovoltaic system, wind turbines, etc., for buildings or in communities. High-percentage renewable power is consumed by cascade grid connection and energy storage to maintain the stability of the power grid.

\subsection{The Planning Approaches}

\subsubsection{Demand Side}

1. Building Sector

The point and surface combination method is used for building sector energy demand reduction. From the point of view of the retrofitting objectives, energy conservation measures can be proposed for existing buildings, and design and construction requirements of energy conservation are proposed for new buildings. Therefore, all of the buildings will 
be constructed by conforming to the national ultra-low energy or near-zero energy building standards.

All existing buildings in MINCEDD will be retrofitted with energy conservation measures by 2030. Standards of ultra-low energy building are required for new buildings so that all new buildings conform to the current national standard "Technical standard for nearly zero energy buildings" [34] by 2030. Buildings built during 2030-2050 conform to the claims for the near-zero energy building standards determined by the current national standard "Technical standard for nearly zero energy buildings" [34]. The specific building performance parameters are listed in Table 5 .

Table 5. Energy conservation measures for buildings.

\begin{tabular}{|c|c|c|c|c|}
\hline \multirow[b]{2}{*}{ Construction Year } & \multicolumn{2}{|c|}{ Residential Buildings } & \multicolumn{2}{|c|}{ Public Buildings } \\
\hline & 2030 & 2050 & 2030 & 2050 \\
\hline \multicolumn{5}{|c|}{ Building Envelope Performance } \\
\hline $\operatorname{Roof}\left(\mathrm{W} / \mathrm{m}^{2} \cdot \mathrm{K}\right)$ & 0.5 & 0.3 & 0.45 & 0.3 \\
\hline External Wall $\left(\mathrm{W} / \mathrm{m}^{2} \cdot \mathrm{K}\right)$ & 0.6 & 0.4 & 0.7 & 0.4 \\
\hline External Window $\left(\mathrm{W} / \mathrm{m}^{2} \cdot \mathrm{K}\right)$ & 1.8 & 1.4 & 1.8 & 1.4 \\
\hline Solar heat gain coefficient (Winter) & $\geq 0.40$ & $\geq 0.40$ & $\geq 0.40$ & $\geq 0.40$ \\
\hline Solar heat gain coefficient (Summer) & $\leq 0.30$ & $\leq 0.30$ & $\leq 0.15$ & $\leq 0.15$ \\
\hline \multicolumn{5}{|c|}{ Equipment Energy Efficiency } \\
\hline Unitary air conditioner (EER) & 4.0 & 4.5 & 4.0 & 4.5 \\
\hline Chiller (COP) & 6.0 & 6.25 & 6.0 & 6.25 \\
\hline Multi-connected split air conditioner $(\operatorname{IPLV}(\mathrm{C}))$ & 5.0 & 6.0 & 5.0 & 6.0 \\
\hline Air-cooled heat pump (heating EER) & 2.0 & 2.3 & 2.0 & 2.3 \\
\hline Air-cooled heat pump (cooling EER) & 3.2 & 3.4 & 3.2 & 3.4 \\
\hline Gas boiler $(\mathrm{D} \leq 2.0 / \mathrm{Q} \leq 1.4)$ & $92 \%$ & $94 \%$ & $92 \%$ & $94 \%$ \\
\hline Gas boiler $(\mathrm{D}>2.0 / \mathrm{Q}>1.4)$ & $94 \%$ & $96 \%$ & $94 \%$ & $96 \%$ \\
\hline Pump ${ }^{1}$ & Level 2 & Level 1 & Level 2 & Level 1 \\
\hline
\end{tabular}

${ }^{1}$ The pump energy efficiency is determined based on the related current national standard for pump.

In terms of surfaces, replicable projects for future community construction in accordance with "Pilot Work Plan for Future Community Construction in Zhejiang Province" are planned. The planning schemes for low-carbon communities are listed in Table 6.

Table 6. Low-carbon communities planning scheme.

\begin{tabular}{ccccccc}
\hline \multirow{2}{*}{ Type of Community } & \multicolumn{2}{c}{$\mathbf{2 0 2 0 - 2 0 2 5}$} & & $\mathbf{2 0 2 6 - 2 0 3 0}$ & $\mathbf{2 0 3 1 - 2 0 4 0}$ & \multirow{2}{*}{$\mathbf{2 0 4 1 - 2 0 5 0}$} \\
\cline { 2 - 6 } & Quantity & Building Area $\left(\mathbf{m}^{\mathbf{2}}\right)$ & Quantity & Building Area $\left(\mathbf{m}^{\mathbf{2}}\right)$ & Building Area $\left(\mathbf{m}^{\mathbf{2}}\right)$ & \\
\hline Hydrogen community & $/$ & $/$ & 3 & 400,000 & & fully \\
Direct current community & 3 & 300,000 & $10-12$ & $1,000,000-1,500,000$ & $7,000,000-9,000,000$ & promoted \\
All electric community & 3 & 300,000 & $10-12$ & $1,000,000-1,500,000$ & \\
Zero energy community & 5 & 500,000 & $10-15$ & $1,000,000-2,000,000$ & \\
\hline
\end{tabular}

After applying the above building energy conservation measures, the building energy demand forecasting results are listed in Tables 7 and 8. Scenario 1 refers to the conventional scenario for 2030, i.e., energy increases under the current rate. Scenarios 2 and 3 refer to the near-zero carbon emission scenarios for 2030 and 2050, respectively.

Table 7. Annual power consumption per building area for Scenarios 1-3 (unit: $\mathrm{kWh} / \mathrm{m}^{2}$ ).

\begin{tabular}{cccc}
\hline Scenario & Residential Building & Shopping Mall + Office & School \\
\hline Scenario 1 & 30 & 150 & 70 \\
Scenario 2 & 21 & 75 & 50 \\
Scenario 3 & 20 & 74 & 47 \\
\hline
\end{tabular}


Table 8. Annual power consumption for Scenarios 1-3 (unit: GWh).

\begin{tabular}{cccccc}
\hline Scenario & $\begin{array}{c}\text { Residential } \\
\text { Building }\end{array}$ & Shopping Mall + Office & School & $\begin{array}{c}\text { Current } \\
\text { Condition }\end{array}$ & Total \\
\hline Scenario 1 & 127 & 686 & 92 & 319 & 1224 \\
Scenario 2 & 82 & 318 & 61 & 319 & 780 \\
Scenario 3 & 130 & 522 & 95 & 319 & 1066 \\
\hline
\end{tabular}

\section{Traffic Sector}

Green transportation and low-carbon travelling are recommended to reduce the amount of energy that is consumed by the traffic sector. In terms of "light-storage-charging" technology, there are seven power charging stations and five hydrogen refueling stations that are planned for green transportation. The vehicles will consume $100 \%$ of clean energy for public utilities, such as buses, taxi, and delivery vehicles, by 2030 and for private cars by 2050 .

\section{Industry Sector}

The industry energy conservation and low-carbon-emission objectives can be achieved by improving equipment efficiency and by integrating energy utilization and industrial restructuring. The introduction of industries with energy consumption per unit output below 0.20 tce/CNY into districts is encouraged. The evaluation and development recommendations for industrial structures are listed in Table 9.

\subsubsection{Supply Side}

In order to achieve the target proportion of renewable energy and renewable power, renewable energy is the major source of energy on the supply side. The scheme for the supply side focuses on photovoltaic and wind power generation and the full utilization of LNG cold energy and hydrogen energy. The renewable energy capacity is planned according to demand forecast results, consuming maximum renewable power, avoiding reverse power transmission, and decreasing peak-valley difference fluctuations. The layout of the energy scheme for the supply side is shown in Figure 9.

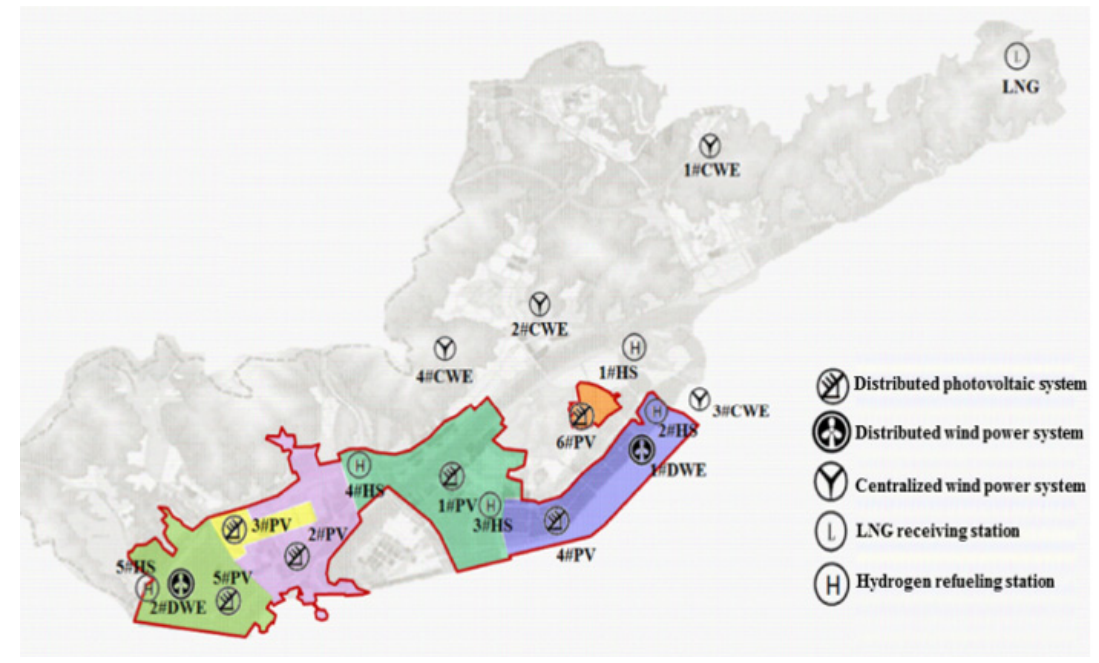

Figure 9. Source-side energy plan layout. 
Table 9. The evaluation and development recommendations of industrial structure.

\begin{tabular}{|c|c|c|c|c|c|c|c|c|c|c|c|c|c|}
\hline \multirow{2}{*}{ Items } & \multirow{2}{*}{$\begin{array}{c}\text { EC } \\
(\%)\end{array}$} & \multirow{2}{*}{$\begin{array}{l}\text { IO } \\
(\%)\end{array}$} & \multirow{2}{*}{$\frac{\mathrm{EC} / \mathrm{O}}{(\mathrm{kgce} / \mathrm{CNY})}$} & \multicolumn{5}{|c|}{ Evaluated Points } & \multicolumn{4}{|c|}{ Evaluation } & \multirow{2}{*}{ Development Recommendation } \\
\hline & & & & EC & Output & $\mathrm{EC} / \mathrm{O}$ & Total & Evaluation & $\mathbf{P}$ & D & $\mathbf{R}$ & $\mathrm{E}$ & \\
\hline Car manufacturer & 29.30 & 52.40 & 0.020 & 71 & 52 & 91 & 214 & 100.00 & $\sqrt{ }$ & & & & Assembly orientated \\
\hline General equipment & 9.90 & 10.40 & 0.025 & 90 & 10 & 89 & 190 & 88.45 & & $\sqrt{ }$ & & & \\
\hline Rubber plastic & 5.30 & 3.30 & 0.040 & 95 & 3 & 83 & 181 & 84.24 & & $\sqrt{ }$ & & & \\
\hline Metalwork & 2.20 & 2.10 & 0.030 & 98 & 2 & 87 & 187 & 87.15 & & $\sqrt{ }$ & & & Reducing plating and casting manufacturing \\
\hline Railways and traffic & 1.40 & 2.40 & 0.020 & 99 & 2 & 91 & 192 & 89.69 & & $\sqrt{ }$ & & & \\
\hline Buildings & 12.20 & 7.00 & 0.045 & 88 & 7 & 80 & 175 & 81.73 & & $\sqrt{ }$ & & & $\begin{array}{c}\text { Developing prefabricated buildings and green and } \\
\text { low-energy buildings }\end{array}$ \\
\hline Other industries & 13.30 & 13.50 & 0.030 & 87 & 14 & 87 & 187 & 87.29 & & $\sqrt{ }$ & & & \\
\hline Gas production & 18.90 & 7.20 & 0.070 & 81 & 7 & 70 & 158 & 73.63 & & & $\sqrt{ }$ & & Recovering cooling energy \\
\hline Textile industry & 5.70 & 1.50 & 0.110 & 94 & 2 & 52 & 148 & 69.02 & & & $\sqrt{ }$ & & Energy consumption control and waste heat recovery \\
\hline Paper making & 1.80 & 0.20 & 0.230 & 98 & 0 & 0 & 98 & 45.89 & & & & $\sqrt{ }$ & Restriction of high-pollution and-demand industries \\
\hline Total & 100.00 & 100.00 & & 900 & 100 & 730 & 1730 & 807.09 & & & & & \\
\hline Peak & 29.30 & 52.40 & 0.230 & 99 & 52 & 91 & 214 & 100.00 & & & & & \\
\hline
\end{tabular}




\section{Solar Energy}

To maximize the photovoltaic (PV) installation, it is suggested to make full use of a building's roof, façade, and structure to design building-integrated photovoltaics (BIPV). The maximum area of factory roofs ( $\geq 60 \%$ of roof area) and available civil building roofs ( $\geq 20 \%$ of roof area) are utilized to install solar photovoltaic systems. The capacity of installed solar photovoltaic systems will increase to $600 \mathrm{MW}$ by 2030 and will increase to $642 \mathrm{MW}$ by 2050. The planning scheme for photovoltaic systems for different types of buildings is detailed in Tables 10 and 11 .

Table 10. PV layout plans for different types of buildings by 2030 (40 MW in existence).

\begin{tabular}{|c|c|c|c|c|c|}
\hline \multirow{2}{*}{ Building Type } & Roof Area & Roof Usage Rate & PV Area & PV Capacity & Power Generation \\
\hline & $\left(\mathrm{m}^{2}\right)$ & $(\%)$ & $\left(\mathrm{m}^{2}\right)$ & (MW) & (GWh) \\
\hline Existing industry & $3,220,000$ & 60 & $1,930,000$ & $1,930,000$ & 193 \\
\hline Residential & 300,000 & 20 & 60,000 & 60,000 & 6 \\
\hline Commercial Office & 910,000 & 20 & 183,000 & 183,000 & 18 \\
\hline Industry & $4,070,000$ & 60 & $2,441,000$ & $2,441,000$ & 244 \\
\hline Education & 190,000 & 20 & 38,000 & 38,000 & 4 \\
\hline Warehouse & $2,260,000$ & 20 & $1,357,000$ & $1,357,000$ & 136 \\
\hline Total & $10,950,000$ & / & $6,009,000$ & $6,009,000$ & 601 \\
\hline
\end{tabular}

Table 11. PV layout plans for different types of buildings by 2050 (40 MW in existence).

\begin{tabular}{|c|c|c|c|c|c|}
\hline \multirow{2}{*}{ Building Type } & Roof Area & Roof Usage Rate & PV Area & PV Capacity & Power Generation \\
\hline & $\left(\mathrm{m}^{2}\right)$ & $(\%)$ & $\left(\mathrm{m}^{2}\right)$ & (MW) & (GWh) \\
\hline Existing industry & $3,217,000$ & 60 & $1,930,200$ & 193.0 & 193 \\
\hline Residential & 332,000 & 20 & 66,500 & 6.6 & 7 \\
\hline Commercial Office & $1,006,000$ & 20 & 201,300 & 20.1 & 20 \\
\hline Industry & $4,475,000$ & 60 & $2,684,800$ & 268.5 & 268 \\
\hline Education & 207,000 & 20 & 41,300 & 4.1 & 4 \\
\hline Warehouse & $2,487,000$ & 20 & $1,492,200$ & 149.2 & 149 \\
\hline Total & $11,724,000$ & - & $6,416,000$ & 641.5 & 641 \\
\hline
\end{tabular}

\section{Wind Energy}

Distributed onshore wind power and offshore wind power will be developed first. Then, centralized onshore wind power will be installed during the period of 2030 2050. The distributed wind power will be installed near factories and warehouses and will be more than $300 \mathrm{~m}$ away from residential areas. Offshore wind power will be installed away from channels and in the areas near the seacoast that are not sheltered. In addition, the installation of onshore wind power generation facilities on the ridge, where the wind resources are superior, is suggested. The wind capacities for different planning periods are shown in Table 12.

Table 12. The wind power capacity.

\begin{tabular}{ccc}
\hline Type & Total Capacity of 2030 (MW) & Total Capacity of 2050 (MW) \\
\hline Distributed wind power & 66 & 131 \\
Offshore wind power & 258 & 337 \\
Onshore wind power & 95 (current condition) & 320 \\
Total & 419 & 788 \\
\hline
\end{tabular}

\section{Hydrogen energy}

It is recommended that hydrogen energy is obtained from industrial by-products and hydrogen electrolysis devices that are powered by surplus renewable power. 
There are five hydrogen refueling stations with a capacity of $500 \mathrm{~kg} / \mathrm{d}$ that are planned according to integrated energy supply stations for the traffic sector. Two of them will be built in the integrated stations by 2030 in order to satisfy the hydrogen demands of buses, delivery vehicles, and transportation vehicles. The other three hydrogen refueling stations will be built by 2050 in order to satisfy the increasing demand for the use of hydrogen in the traffic sector in the future. Furthermore, the main applications are the construction of hydrogen refueling stations, household hydrogen fuel cells, hydrogen fuel vehicles, and trucks. Hydrogen will be partially mixed with natural gas and will used for cooking and heating in buildings in the long term. The overall utilization plan for hydrogen energy is shown in Figure 10.

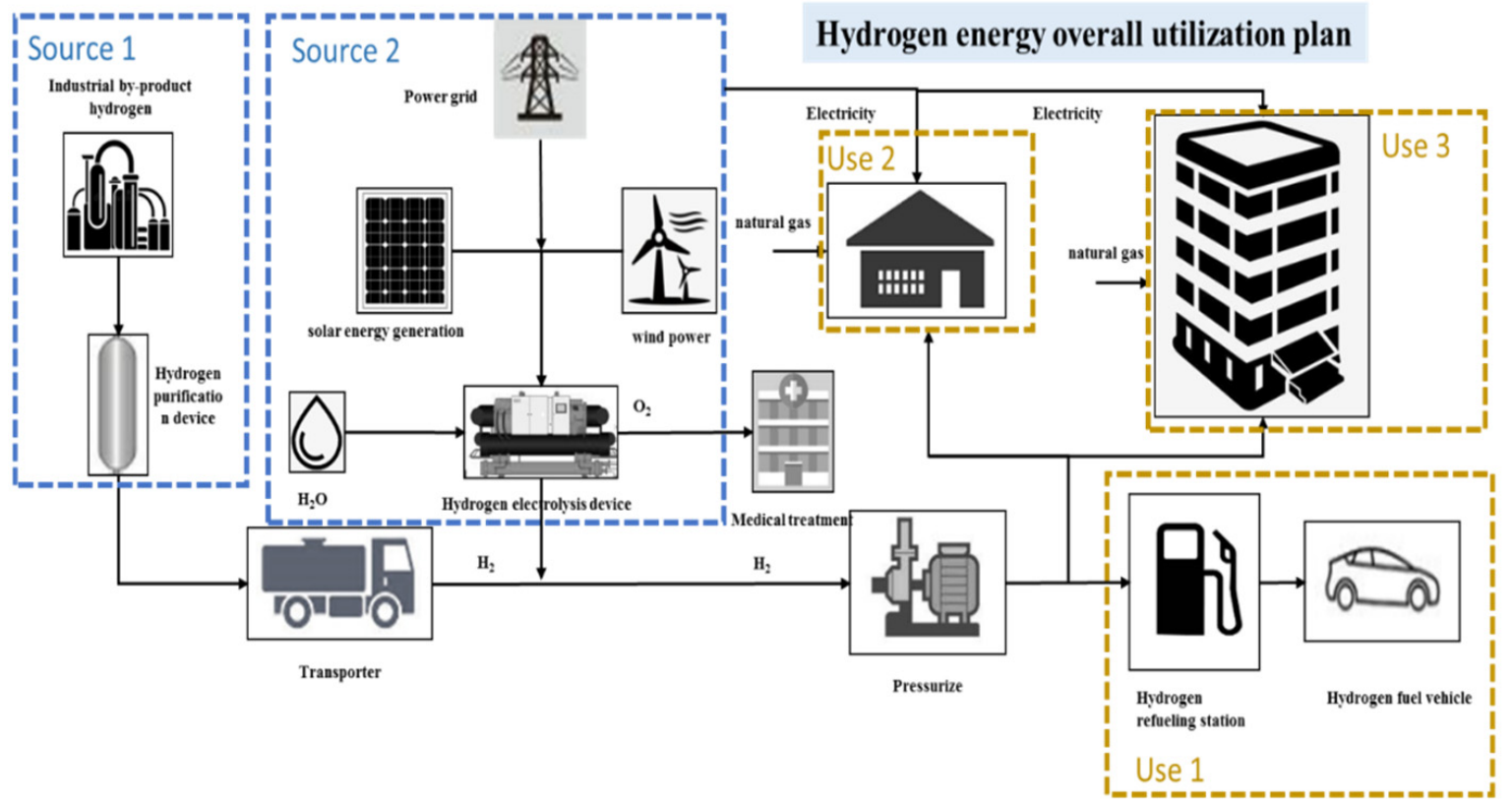

Figure 10. The overall utilization plan for hydrogen energy.

\section{LNG cold energy}

There is currently an LNG receiving station with a capacity of 7 Mton in the MINCEDD. Cold energy can be released and utilized after the LNG is gasified.

A cold energy cascade utilization industrial area that includes air separation, $\mathrm{CO}_{2}$ liquefaction and dry ice manufacturing, medical refrigeration, and a data center is planned near the receiving station. Simultaneously, the natural gas that is produced after the gasification of LNG can be used for office buildings or small-scale commercial tri-generation system fuel cells in industrial parks and in surrounding areas. The layout proposed in the diagram of the industrial park is in Figure 11, and the LNG cold energy cascade utilization process is shown in Figure 12.

\subsubsection{Grid Side}

The port, industry, city, transportation, urban energy grid, green transport charging grid, and port microgrid will be planned, all of which compose the green energy grid that is required for energy dispatch.

\section{Urban Energy Grid}

In the MINCEDD, renewable energy mainly includes wind energy and solar energy. The scheme through which renewable energy will be connected to the grid is illustrated in Figure 13. 


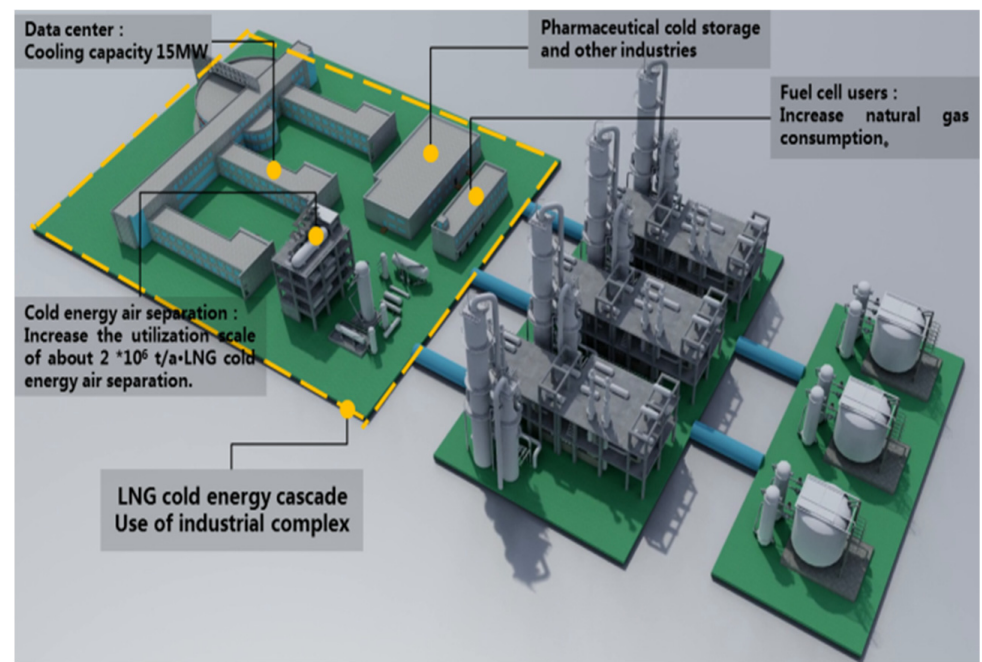

Figure 11. Schematic diagram of LNG cold energy industry layout.

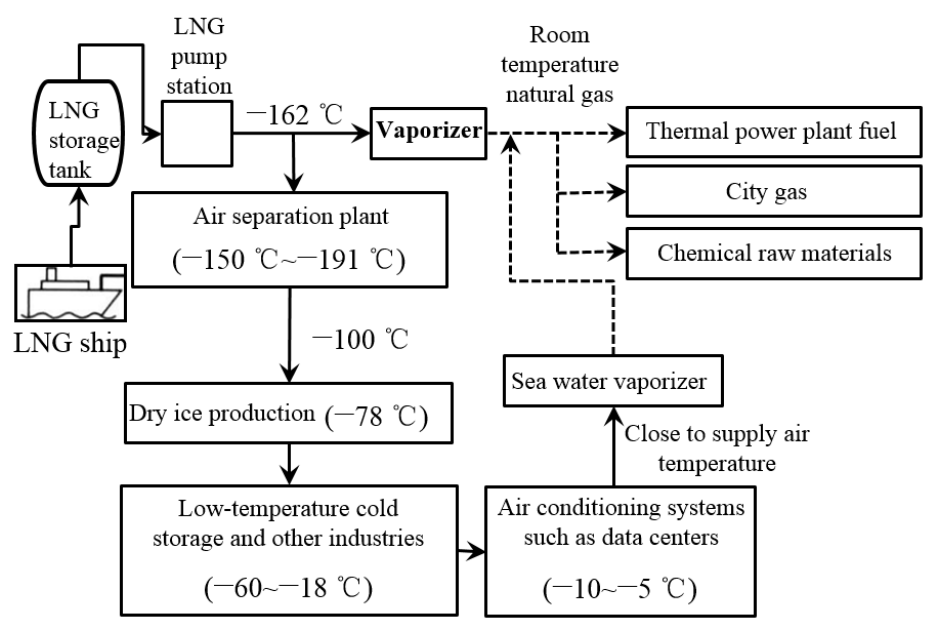

Figure 12. LNG cold energy cascade utilization flow chart.

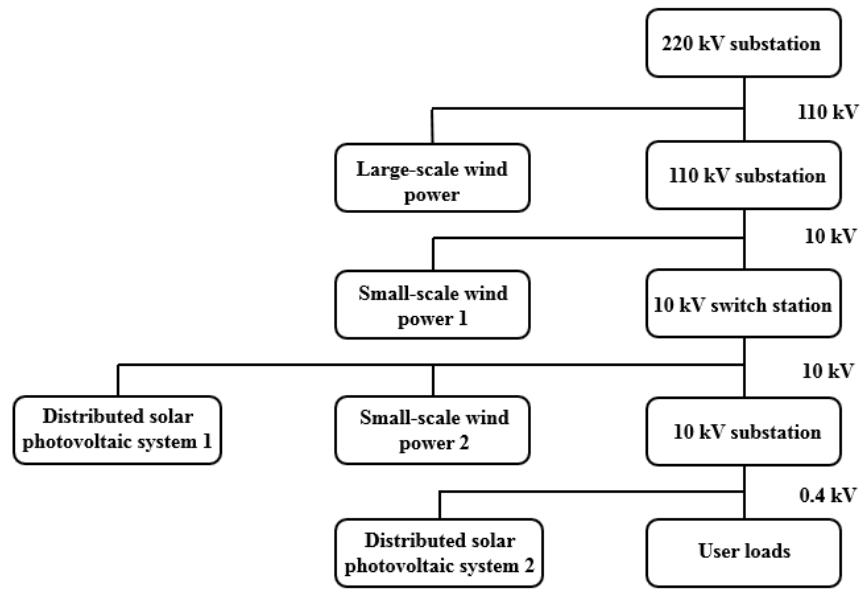

Figure 13. The scheme through which renewable energy will be connected to the grid.

The voltage that is necessary for solar PV to connect is $0.4 \mathrm{kV}$. The voltage of the rest power is increased to $10 \mathrm{kV}$ in order to continue consumption when the consuming ability under $0.4 \mathrm{kV}$ is insufficient. Small and large amounts of wind power are preferentially connected to the $10 \mathrm{kV}$ and $110 \mathrm{kV}$ substations, respectively. This means that small and large amounts of wind power can be connected to the secondary side of the $220 \mathrm{kV}$ substation, 
the secondary side of the $110 \mathrm{kV}$ substation, and the $10 \mathrm{kV}$ switching station, which is based on a different scale. PV facilities are widely distributed in the planning area and are suitable for connecting to the $0.4 \mathrm{kV}$ voltage class, which is mainly intended for self-use.

\section{Green Transport Charging Grid}

The charging infrastructures for electric vehicles (EV) and hydrogen energy vehicles are EV charging stations and hydrogen refueling stations, respectively, whose layouts constitute the green transport charging grid in Figure 14.

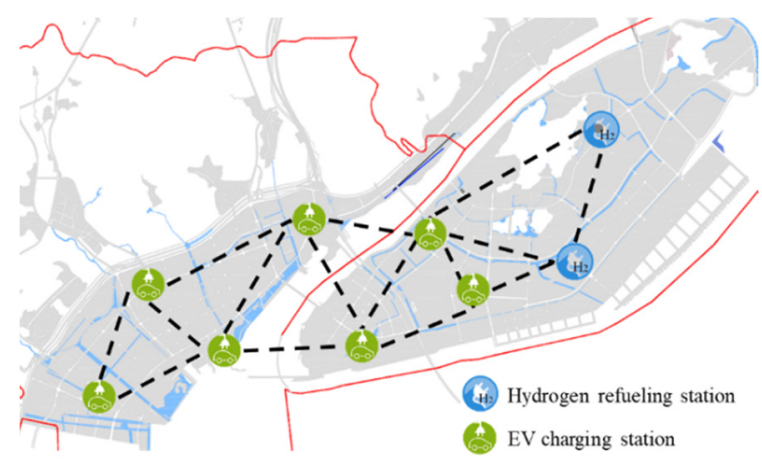

Figure 14. The layout of charging infrastructures.

According to the principle of optimal land utilization and the use characteristics of EVs, it is suggested that charging stations should be built together with existing public service facilities. PV devices can be installed on the ceiling of the charging station to increase the renewable energy use.

A hydrogen refueling station will be built in the Li'ao area, which is located on the main roads and is in a location that is convenient for hydrogen vehicle users. Additionally, a hydrogen refueling station will be built in the port area during long-term planning.

\section{Port Microgrid}

The concept of an onshore power supply is regarded as an effective solution to make ports free of greenhouse gas emissions, air pollutants, vibrations, and noise pollution.

The Meishan port is located in the southeast of the zero carbon emission demonstration area. The port has 10 berths. Shore power facilities will be built successively for each berth and will be able to output $50 \mathrm{~Hz}$ and $60 \mathrm{~Hz}$ alternating currents (AC) with a voltage class of $6.6 \mathrm{kV}$.

An AC/DC hybrid microgrid will be built in the port area for shore-to-ship power, which can improve the utilization of renewable energy distributed in the port area. The microgrid is shown in Figure 15.

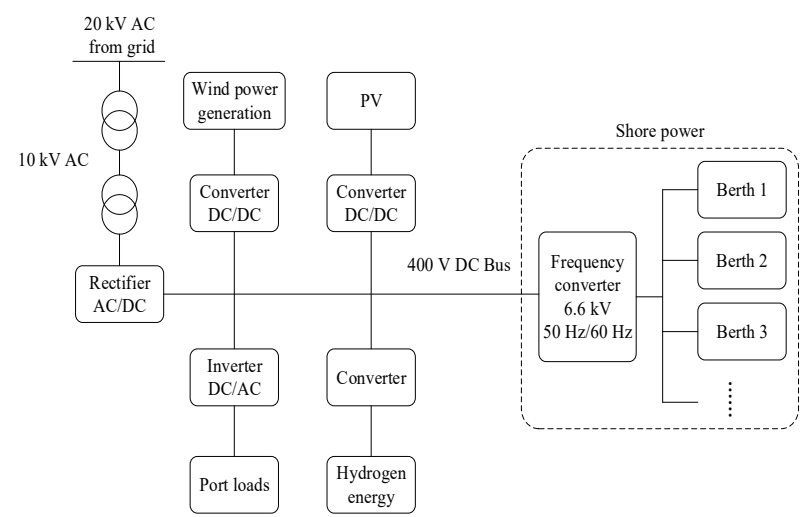

Figure 15. The hybrid micro-grid in the port. 
In addition, hydrogen energy applications will be explored in transport ships and in logistics vehicles.

\subsubsection{Storage Side}

According to different types of energy and demands in near-zero carbon emission demonstration districts, multiple energy storage facilities are planned, which will consist of electrical energy storage (EES), thermal energy storage (TES), hydrogen storage, and compressed air energy storage (CAES) facilities. EES and TES can handle energy balances from the supply and demand sides in time series. Hydrogen storage and CAES facilities are oriented to the actual needs of industrial production.

\section{Electrical Energy Storage}

EES can transform electrical energy from power grids into a storable form and can ensure that it can be converted back into electrical energy if needed.

In the MINCEDD, there is no suitable terrain to construct pumped hydro storage facilities. Therefore, battery energy storage is widely utilized in this plan. There are three major ways to apply battery energy storage, which are as follows:

PV with small-scale battery energy storage

In order to maximize solar energy use and reduce the peak-valley difference, residential, commercial, and industrial users should be encouraged to install PV with small-scale battery energy storage for self-use with the $0.4 \mathrm{kV}$ access voltage class. A battery storage device operating from $0.1 \mathrm{kWh}$ to $0.2 \mathrm{kWh}$ can be allocated for each kilowatt PV device. Users will be able to obtain a one-time subsidy for battery energy storage devices.

- Medium-scale power storage facilities on the user side

Users with a large peak-valley difference, such as those in offices and commercial buildings, should be encouraged to install medium-scale power storage facilities on the user side, and these users will receive one-time subsidy for the installation of these power storage facilities and discounted electricity prices.

- Large-scale centralized power storage facilities

Around the substation, centralized power storage facilities will be built to reduce load fluctuation and to improve the stability of the power distribution grid.

\section{Thermal Energy Storage}

TES refers to the temporary storage of thermal energy and is able to increase the utilization of thermal energy equipment. For the cold energy demand in industrial areas, cold energy storage facilities will be built to store cold energy during the valley-load period and will release it during the peak-load period, which can restrain the fluctuation that take place during load cooling and will allow industrial and residential demand to be met.

\section{Hydrogen Storage}

Hydrogen can be stored directly for use in fuel cells or can be transported to users. In the planned district, hydrogen storage facilities will be built for fuel cell vehicles and residential functions.

\section{Compressed Air Energy Storage}

In CAES systems, a compressor driven by off-peak or low-cost electricity is used to store energy by compressing air into an air reservoir. Since the self-discharge that is generated by CAES is very low, it can act as a long-term storage device. In addition, the investment cost for CAES is obviously low. In the industrial area, CAES facilities will be planned and constructed for the automobile production industry.

5. The Layout of Energy Storage Facilities

Based on land-use load types, the layout of energy storage facilities is planned as depicted in Figure 16. 


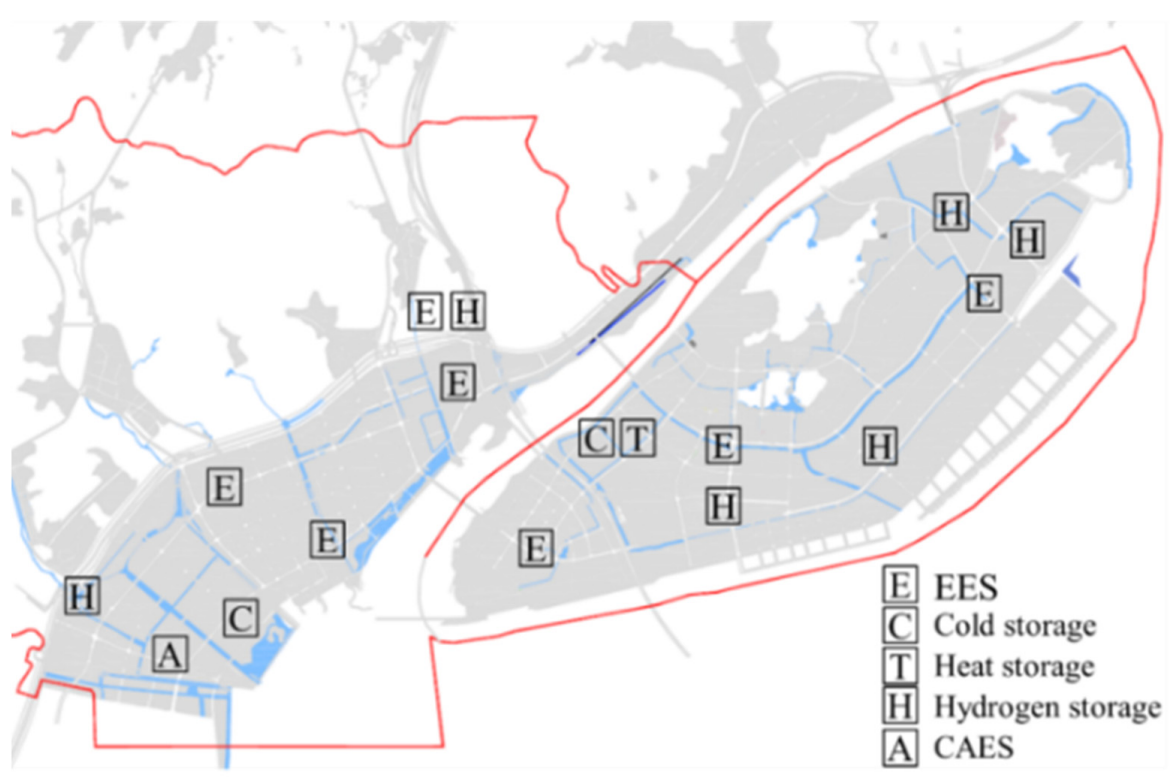

Figure 16. The layout of energy storage facilities.

According to the load forecast and the capacity of renewable energy sources that will be installed for the planning year (2030), the total capacity of the energy storage facilities will need to be about $300 \mathrm{MWh}$ (electricity) in order to maximize the renewable energy power generation consumption, avoid the generation of renewable energy power generation, and reduce the fluctuations in the peak-valley differences. The capacities of the different storage types are listed in Table 13.

Table 13. The capacities of different storage types.

\begin{tabular}{cc}
\hline Storage Types & Capacity \\
\hline PV + Small-scale & $60 \mathrm{MWh}$ \\
Battery Energy Storage & $80 \mathrm{MWh}$ \\
Medium-scale Power Storage & $20 \mathrm{MWh}$ \\
Large-scale Centralized & $30 \mathrm{MWh}$ (heating) \\
Power Storage & $60 \mathrm{MWh}($ cooling) \\
Heat Storage & $2500 \mathrm{~kg}$ \\
Cold Storage & $30 \mathrm{MWh}$ \\
Hydrogen Storage & CAES
\end{tabular}

\subsection{The Planning Safeguard Measures}

The MINCEDD planning scheme was proposed for the planning period from 2020 to 2050. The planning safeguard measures are under development by local governemnts and organizations currently. However, in order to achieve the planned scheme, safeguard measures in terms of technical measures and policies and subsidies are proposed in this article. Additionally, it is suggested that the local governemnts and organizations should make safeguard measures based on these measures.

\subsubsection{Technical Measures}

An integrated energy management platform is planned to be constructed to provide technical support for the realization of the planning scheme. As a district integrated energy service provider, it is considered to build a comprehensive energy monitoring and management platform based on $5 \mathrm{G}$ mobile internet. This platform is used as the hardware foundation, which can be combined with big data analysis to promote the implementation of energy conservation management and user behavior for energy conservation in the MINCEDD. 
The platform is connected to the users to collect energy demand data and to the district energy supply system to collect the energy supply data from renewable energy systems, gas distributed energy supply systems, waste heat utilization systems, and energy storage systems. Hence, the comprehensive management and dispatch of energy demand and supply can be achieved through the platform. There are four modules for the operation of the platform, which are listed in Table 14.

Table 14. The integrated energy management platform modules.

\begin{tabular}{cc}
\hline Module Name & Functions \\
\hline User energy management module & Energy consumption analysis, energy efficiency evaluation, user power management \\
Energy supply management module & $\begin{array}{c}\text { Energy index analysis, energy supply quality analysis, energy supply optimization analysis } \\
\text { Energy transaction management module } \\
\text { Special value-added service module }\end{array}$ \\
\hline
\end{tabular}

\subsubsection{Policies and Subsidies}

The energy planning indexes that consist of renewable and clean energy capacity, energy conservation parameters for building, industrial and traffic sectors, grid capacity, and storage capacity can be included into land grant clauses during land bidding. After that, the indexes are committed to be implemented by developers or constructors during the construction period, whereby the planning indexes can be achieved.

Apart from the land grant clauses, policies and subsidies are formulated to ensure that the planning approaches are carried out (see Table 15).

Table 15. The policies and subsidies for the planning scheme implementation.

\begin{tabular}{|c|c|c|}
\hline Planning Approach Category & Policies and Subsidies & Related Department \\
\hline Solar PV & Subsidies for distributed PV & The management committee of the MINCEDD \\
\hline Wind power & Subsidies for distributed wind power & $\begin{array}{l}\text { The management committee, the development } \\
\text { and reform committee, and the land and } \\
\text { resources bureau of the MINCEDD }\end{array}$ \\
\hline LNG energy & $\begin{array}{l}\text { Subsidies and measures for the introduction of } \\
\text { LNG energy utilization industries }\end{array}$ & $\begin{array}{c}\text { The development and reform committee of } \\
\text { the MINCEDD }\end{array}$ \\
\hline Hydrogen energy & $\begin{array}{c}\text { Subsidies for hydrogen production from } \\
\text { renewable energy }\end{array}$ & $\begin{array}{c}\text { The development and reform committee of } \\
\text { the MINCEDD }\end{array}$ \\
\hline Building energy conservation & Subsidies for ultra-low energy buildings & The management committee of the MINCEDD \\
\hline Low carbon communities & $\begin{array}{l}\text { Subsidies for the equipment of direct current low } \\
\text { carbon communities, and hydrogen fuel cells }\end{array}$ & $\begin{array}{l}\text { The management committee, the development } \\
\text { and reform committee, and the power grid } \\
\text { companies of the MINCEDD }\end{array}$ \\
\hline Industry energy conservation & $\begin{array}{l}\text { Measures for the introduction of high-tech or } \\
\text { low-carbon green industries }\end{array}$ & $\begin{array}{l}\text { The management committee, and the economic } \\
\text { and information committee of the MINCEDD }\end{array}$ \\
\hline Green traffic & $\begin{array}{c}\text { Subsidies for electric vehicle charging facilities; } \\
\text { preferential electricity price for public } \\
\text { charging facilities }\end{array}$ & $\begin{array}{l}\text { The management committee, and power grid } \\
\text { companies of the MINCEDD }\end{array}$ \\
\hline Power distribution grid & $\begin{array}{l}\text { Measures for renewable power accessing to } \\
\text { power distribution grid }\end{array}$ & $\begin{array}{l}\text { The development and reform committee, and the } \\
\text { power grid companies of the MINCEDD }\end{array}$ \\
\hline Smart green port & $\begin{array}{l}\text { Subsidies or preferential electricity price for the } \\
\text { electricity of the ports }\end{array}$ & $\begin{array}{l}\text { The management committee, the development } \\
\text { and reform committee, and the port office of } \\
\text { the MINCEDD }\end{array}$ \\
\hline
\end{tabular}

\section{Planning Evaluation}

\subsection{Indexes Analysis}

\subsubsection{Proportion of Renewable Energy to Primary Energy}

The authors of [32] propose that the proportion of non-fossil-fuel-based energy consumption increase to $20 \%$ by 2020 . The current shares of renewable energy sources are 39.3 MW for solar PV, 94.5 MW for onshore wind power, and $32 \mathrm{MW}$ for biomass. During the planning period, the capacities of solar PV and wind power will be increased to $642 \mathrm{MW}$ and $788 \mathrm{MW}$ by 2050. However, the biomass capacity will be kept the same due to the selected location and garbage odor concerns in that area. The total amount of renewable energy that will be used by 2030 is $460 \mathrm{ktce}$ and $890 \mathrm{ktce}$ by 2050. The authors of [32] 
estimate that the primary energy consumption will be 625 ktce by 2030 and 650 ktce by 2050. Therefore, the proportions of renewable energy to total primary energy will be $73 \%$ by 2030 and $108 \%$ by 2050, which are slightly higher than the planning objectives. Table 16 displays the current and planned renewable energy conditions.

Table 16. Current and planned renewable energy conditions.

\begin{tabular}{|c|c|c|c|c|c|c|c|}
\hline \multirow{2}{*}{\multicolumn{2}{|c|}{ Projects }} & \multicolumn{2}{|c|}{ Current Condition } & \multicolumn{2}{|c|}{ by 2030} & \multicolumn{2}{|c|}{ by 2050} \\
\hline & & $\begin{array}{c}\text { Installed } \\
\text { Capacity (MW) }\end{array}$ & $\begin{array}{l}\text { Annual Energy } \\
\text { Saving (ktce) }\end{array}$ & $\begin{array}{c}\text { Installed } \\
\text { Capacity (MW) }\end{array}$ & $\begin{array}{l}\text { Annual Energy } \\
\text { Saving (ktce) }\end{array}$ & $\begin{array}{c}\text { Installed } \\
\text { Capacity (MW) }\end{array}$ & $\begin{array}{l}\text { Annual Energy } \\
\text { Saving (ktce) }\end{array}$ \\
\hline \multicolumn{2}{|c|}{ Solar PV } & 39.3 & 10 & 601 & 146 & 642 & 156 \\
\hline \multirow{3}{*}{ Wind power } & Distributed & 0 & 0 & 66 & 32 & 131 & 63 \\
\hline & Offshore & 0 & 0 & 258 & 171 & 337 & 222 \\
\hline & Onshore & 94.5 & 62 & 94.5 & 62 & 319.5 & 211 \\
\hline \multicolumn{2}{|c|}{ Biomass } & 32 & 48 & 32 & 48 & 32 & 48 \\
\hline \multicolumn{2}{|c|}{ Total } & 165.8 & 120 & 1052 & 459 & 1462 & 700 \\
\hline
\end{tabular}

\subsubsection{Proportion of Renewable Power to Total Power Consumption}

Renewable power can be calculated by multiplying the installed capacity by the amount of power generated per unit capacity that is estimated according to past applications. In 2017, the total amounts of renewable power being consumed were $39.3 \mathrm{MW}$ for solar PV, 94.5 MW for wind power, and $32 \mathrm{MW}$ for biomass. The total amount of existing and planned renewable energy used by 2050 is $600 \mathrm{MW}$ for solar PV, $419 \mathrm{MW}$ for wind power, and $32 \mathrm{MW}$ for biomass, with 1883 GWh of electricity being generated by 2030. The installed capacity of solar PV, wind power, and biomass is expected to be $642 \mathrm{MW}$, $788 \mathrm{MW}$, and $32 \mathrm{MW}$, respectively, by 2050. This can generate $2873 \mathrm{GWh}$ of electricity by 2050. Furthermore, the MINCEDD is expected to consume $1928 \mathrm{GWh}$ and $2581 \mathrm{GWh}$ of power by 2030 and 2050, respectively. Hence, the RP/PC of the MINCEDD is expected to be $98 \%$ by 2030 and $111 \%$ by 2050 . This means that the renewable power generated by 2030 can cover almost all of the electricity consumption in the district. Moreover, as the installed capacity of the renewable power is expected to increase and the electricity consumption is expected to decrease by 2050, the amount of renewable power that is generated will be greater than the electricity consumed. Therefore, the index of RP/RC is over $100 \%$. The surplus of renewable power can be supplied to the national power grid for users outside the MINCEDD. Renewable energy generation is listed in Table 17.

Table 17. Current and planned renewable energy generation.

\begin{tabular}{|c|c|c|c|c|c|c|c|}
\hline \multirow{2}{*}{\multicolumn{2}{|c|}{ Projects }} & \multicolumn{2}{|c|}{ Current Condition } & \multicolumn{2}{|c|}{ by 2030} & \multicolumn{2}{|c|}{ by 2050} \\
\hline & & $\begin{array}{c}\text { Installed } \\
\text { Capacity (MW) }\end{array}$ & $\begin{array}{c}\text { Annual } \\
\text { Amount (GWh) }\end{array}$ & $\begin{array}{c}\text { Installed } \\
\text { Capacity (MW) }\end{array}$ & $\begin{array}{c}\text { Annual } \\
\text { Amount (GWh) }\end{array}$ & $\begin{array}{c}\text { Installed } \\
\text { Capacity (MW) }\end{array}$ & $\begin{array}{c}\text { Annual } \\
\text { Amount (GWh) }\end{array}$ \\
\hline \multicolumn{2}{|c|}{ Solar PV } & 39.3 & 39 & 601 & 600 & 642 & 640 \\
\hline \multirow{3}{*}{ Wind power } & Distributed & 0 & 0 & 66 & 130 & 131 & 260 \\
\hline & Offshore & 0 & 0 & 258 & 700 & 337 & 910 \\
\hline & Onshore & 94.5 & 255 & 94.5 & 255 & 319.5 & 865 \\
\hline \multicolumn{2}{|c|}{ Biomass } & 32 & 198 & 32 & 198 & 32 & 198 \\
\hline \multicolumn{2}{|c|}{ Total } & 165.8 & 492 & 1052 & 1883 & 1462 & 2873 \\
\hline
\end{tabular}

\subsection{3. $\mathrm{CO}_{2}$ Emission Reduction}

The 13th Five-Year National Energy Plan and the 13th Five-Year Plan for Low Carbon Development in the Zhejiang province indicated that $\mathrm{CO}_{2}$ emissions will be reduced by $18 \%$ by 2020 compared to 2015 [35]. The reductions in $\mathrm{CO}_{2}$ emissions can be divided into supply side reductions and demand side reductions. Supply side reductions are caused by the application of renewable energy, hydrogen energy, LNG cascade utilization, and geothermal energy, and demand side reductions are caused by industrial waste energy and distributed energy station applications. 
Compared to the current conditions, $\mathrm{CO}_{2}$ emissions on the supply side are expected to be reduced by 0.46 Mton and 0.77 Mton by 2030 and 2050, respectively. Additionally, on the demand side, reductions of 0.32 Mton by 2030 and 0.44 Mton by 2050 are expected. The authors of [32] estimated that $\mathrm{CO}_{2}$ emissions from the MINCEDD will be 1.08 Mton by 2030 and 1.20 Mton by 2050, both of which are under the benchmark scenario in which the district is developed without $\mathrm{CO}_{2}$ reduction measures. The total $\mathrm{CO}_{2}$ reduction rate is expected to approach $70 \%$ and $100 \%$, respectively, by 2030 and 2050. This indicates that the $\mathrm{CO}_{2}$ emissions in the MINCEDD are expected to be nearly zero by 2050, leading to the MINCEDD being in a near-zero carbon district. The $\mathrm{CO}_{2}$ reductions for the supply side and demand side are listed in Table 18.

Table 18. The $\mathrm{CO}_{2}$ emission reductions of the source and demand side.

\begin{tabular}{|c|c|c|c|c|c|c|}
\hline \multirow[b]{2}{*}{ Projects } & \multicolumn{2}{|c|}{ Current Condition } & \multicolumn{2}{|c|}{ by 2030} & \multicolumn{2}{|c|}{ by 2050} \\
\hline & $\begin{array}{c}\text { Installed } \\
\text { Capacity (MW) }\end{array}$ & $\begin{array}{c}\text { Annual } \mathrm{CO}_{2} \\
\text { Reduction (ton) }\end{array}$ & $\begin{array}{c}\text { Installed } \\
\text { Capacity (MW) }\end{array}$ & $\begin{array}{c}\text { Annual } \mathrm{CO}_{2} \\
\text { Reduction (ton) }\end{array}$ & $\begin{array}{c}\text { Installed } \\
\text { Capacity (MW) }\end{array}$ & $\begin{array}{c}\text { Annual } \mathrm{CO}_{2} \\
\text { Reduction (ton) }\end{array}$ \\
\hline Solar PV & 39.3 & 11,000 & 601 & 177,000 & 642 & 188,000 \\
\hline Distributed & / & / & 66 & 38,000 & 131 & 77,000 \\
\hline Wind power Offshore & 1 & 1 & 258 & 206,000 & 337 & 268,000 \\
\hline Onshore & 94.5 & 75,000 & 94.5 & 75,000 & 319.5 & 255,000 \\
\hline Biomass & 32 & 58,000 & 32 & 58,000 & 32 & 58,000 \\
\hline Hydrogen energy & / & / & $\begin{array}{l}\text { 12.6 MW fuel cell + } \\
2 \text { hydrogen stations }\end{array}$ & 12,000 & $\begin{array}{c}30 \mathrm{MW} \text { fuel cell + } 5 \\
\text { hydrogen stations }\end{array}$ & 27,000 \\
\hline LNG cascade utilization & / & / & $\begin{array}{c}800,000 \text { ton } \\
\mathrm{LNG} / \mathrm{yr}\end{array}$ & 41,000 & $\begin{array}{l}800,000 \text { ton } \\
\mathrm{LNG} / \mathrm{yr}\end{array}$ & 40,000 \\
\hline Geothermal energy & / & / & 42.75 & 600 & 78.84 & 1100 \\
\hline $\begin{array}{l}\text { Distributed energy } \\
\text { stations sourced by } \\
\text { natural gas }\end{array}$ & / & / & $\begin{array}{ll}\text { - } & \text { fuel cell: } \\
\text { - } & 4.5 \mathrm{MW} ; \\
& \text { centrifugal } \\
\text { cooling: } \\
\text { 16,000 RT; } \\
\text { - } \quad \text { absorption } \\
\text { cooling: } \\
\text { 1000 RT; } \\
\text { boilers: } \\
46 \mathrm{t} / \mathrm{h}\end{array}$ & 300 & $\begin{array}{ll}\text { - } & \text { fuel cell: } \\
\text { - } & 4.5 \mathrm{MW} ; \\
& \text { centrifugal } \\
& \text { cooling: } \\
& 16,000 \mathrm{RT} ; \\
\text { - } & \text { absorption } \\
& \text { cooling: } \\
& 1000 \mathrm{RT} ; \\
\text { - } & \text { boilers: } \\
& 46 \mathrm{t} / \mathrm{h}\end{array}$ & 300 \\
\hline Total source side reduction & / & 145,000 & / & 608,000 & / & 915,000 \\
\hline Demand side reduction & The measures & $\begin{array}{l}\text { tilding energy con } \\
\text { demand side } \mathrm{CO}_{2}\end{array}$ & $\begin{array}{l}\text { vations, industrial wa } \\
\text { duction is estimated a }\end{array}$ & $\begin{array}{l}\text { heat utilization, etc } \\
20,000 \text { ton by } 2030\end{array}$ & $\begin{array}{l}\text { re implemented on the } \\
440,000 \text { ton by } 2050 \text {. }\end{array}$ & mand side. The \\
\hline Total reduction & / & 145,000 & / & 928,000 & / & $1,355,000$ \\
\hline
\end{tabular}

\subsection{Indexes Comparison}

The MINCEDD indexes are compared to the similar indexes of the international project and other districts outside of Zhejiang. The results show that the MINCEDD indexes are all more advanced than other indexes.

\subsubsection{Indexes Comparison with the International Project}

The "Ningbo Meishan Near-Zero Carbon Emission Demonstration Zone Construction Planning and International Cooperation Research Project Technical Report" [32] is a preliminary international project that details the energy planning scheme for the MINCEDD. The MINCEDD energy plan that is introduced in this paper is developed based on the four aspects of the demand side, supply side, grid side, and storage side. The results show that the RE/PE is expected to reach $73 \%$ and that the RP/PC is expected to reach $98 \%$ by 2030 . The MINCEDD indexes are more advanced than those determined in the international project (see Table 19).

Table 19. Comparison of the MINCEDD indexes and the international project.

\begin{tabular}{ccccc}
\hline \multirow{2}{*}{ Index } & \multicolumn{2}{c}{ MINCEDD } & \multicolumn{2}{c}{ The International Project } \\
\cline { 2 - 5 } & $\mathbf{2 0 3 0}$ & $\mathbf{2 0 5 0}$ & $\mathbf{2 0 3 0}$ & $\mathbf{2 0 5 0}$ \\
\hline $\mathrm{RE} / \mathrm{PE}$ & $73 \%$ & $108 \%$ & $71.4 \%$ & $93.8 \%$ \\
$\mathrm{RP} / \mathrm{PC}$ & $98 \%$ & $111 \%$ & $90 \%$ & $100 \%$ \\
\hline
\end{tabular}




\subsubsection{Indexes Comparison with Demonstration Districts outside Zhejiang}

The MINCEDD was one of the five demonstration project plans for China State Grid in 2019, and the remaining four demonstration projects are the Beidaihe Integrated Energy Demonstration District (IEDD), the Zhengding IEDD, the Lankao IEDD, and the Guzhenkou IEDD [36].

The RE/PE for the Beiudaihe IEDD was $20 \%$ for 2020 and is $20 \%$ for the Zhending IEDD by 2030. In addition, the $\mathrm{CO}_{2}$ emission reduction rate is expected to reach $15 \%$ by 2030. The RE/PE and the RP/PC for the Lankao IEDD were greater than $60 \%$ and $90 \%$, respectively, in 2021. There is no specific energy-related index that has been identified for the Guzhenkou IEDD because the energy plan is focused on an intelligent power grid.

Compared to the indexes above, the indexes of RE/PE and RP/PC of the MINCEDD are higher than that of both the Beidaihe IEDD and Zhending IEDD. The RP/PC of the MINCEDD is expected to be at relatively the same level as that of the Lankao IEDD by 2030. In summary, the indexes of the MINCEDD are relatively more advanced than those of other demonstration districts outside of Zhejiang. The detailed indexes are listed in Table 20.

Table 20. The comparison of the MINCEDD indexes and those of other districts outside of Zhejiang.

\begin{tabular}{ccccccc}
\hline District & \multicolumn{2}{c}{ MINCEDD } & Beidaihe IEDD [37] & \multicolumn{2}{c}{ Zhengding IEDD [38] } & Lankao IEDD [39] \\
\hline Year & $\mathbf{2 0 3 0}$ & $\mathbf{2 0 5 0}$ & $\mathbf{2 0 2 0}$ & $\mathbf{2 0 2 0}$ & $\mathbf{2 0 3 0}$ & $\mathbf{2 0 2 1}$ \\
$\mathrm{RE} / \mathrm{PE}$ & $73 \%$ & $108 \%$ & $\geq 20 \%$ & $3 \%$ & $20 \%$ & $\geq 60 \%$ \\
$\mathrm{RP} / \mathrm{PC}$ & $98 \%$ & $111 \%$ & $/$ & $/$ & $/$ & $\geq 90 \%$ \\
$\mathrm{CO}_{2}$ emission reduction rate & $70 \%$ & $100 \%$ & $/$ & $10 \%$ & $15 \%$ & $/$ \\
\hline
\end{tabular}

\section{Conclusions and Recommendations}

Energy consumption in developed urban areas is relatively high. Moreover, the renewable energy and carbon sequestration resources in these areas are limited. Integrated energy planning methods and schemes for NCEDDs in urban areas have been proposed in this paper to provide a reference for urban energy planning with near-zero carbon emission objectives.

A three-step planning method was proposed for the integrated energy planning of NCEDDs in urban areas that allows objectives to be determined, planning strategies to be established, and planning approaches to be proposed. Planning strategies include reducing energy demand; improving the energy efficiency of building, industry, and traffic sectors; and utilizing renewable energy sources that have been adapted to local conditions. Approaches are proposed according to these strategies, which encompass reducing energy demand and increasing renewable energy applications on the demand side and supply side, respectively, as well as improving energy interconnection and peak-valley differences in power levels.

The integrated energy planning for the MINCEDD was investigated as a case study to explain the planning method and scheme. The $\mathrm{CO}_{2}$ emission reduction objectives in the MINCEDD are 0.75 Mton and 1.1 Mton by 2030 and 2050, respectively. The planned results show that annual $\mathrm{CO}_{2}$ emissions will be reduced by 0.78 Mton by 2030 and 1.21 Mton by 2050 through the implementation of approaches that are related to the supply, demand, grid, and storage points of view. Furthermore, the $\mathrm{CO}_{2}$ emission rates are expected to approach $70 \%$ and $100 \%$ by 2030 and 2050, respectively. Compared to the other districts with an integrated energy planning scheme, the renewable energy utilization and $\mathrm{CO}_{2}$ emission reduction performances are relatively advanced in the MINCEDD.

In addition to the approaches proposed in this case study, other innovative measures can be implemented according to local conditions of the planned district. For example, energy buses (Ebus) (i.e., fifth-generation district energy network) are recommended for future integrated energy planning in urban areas, which provides opportunities for sharing heating and cooling energy under ultra-low temperature conditions compared to those of fourth-generation energy systems. Moreover, these measures can improve system efficiency 
by capturing low-grade heat sources and waste heat, which is an advanced heat recovery and energy synergy method that can be implemented in various building types [40].

Moreover, this method is only being used a few cases at present, and its feasibility needs to be verified and improved through continuous use. Therefore, this method should be used reasonably according to the characteristics of the project and should not be copied completely when planning demonstration districts. Although this method can ensure the rationality of the energy plan to a certain extent, it cannot guarantee the implementation of these plans. Therefore, when planning a demonstration district, it is necessary to clarify the implementation factors of the planned energy schemes, including the scenarios, location, stages, capacities, energy efficiencies, etc., of the applications of energy systems. In addition, it is necessary to implement safeguard measures to ensure the implementation of the plan. The safeguard measures can be policy requirements; financial subsidy support, the establishment of management platforms, publicity and guidance; the development of integrated energy service operation models; innovative energy business models; etc. Apart from the technical measures, the three-step planning method and the integrated energy planning scheme should be carried out with policies and incentives issued by the government and organizations to ensure its implementation. Future research into the implementation of this three-step planning method for other NCEDD should be conducted to demonstrate the rationality, feasibility, and limitations of this conducted research. It is suggested that this NCEDD planning case study be used as a reference in future projects.

Author Contributions: Writing—original draft preparation, X.X., Y.W., Y.Z. and H.J.; writing—review and editing, X.X.; supervision, Y.R. and J.W.; project administration, Y.R. and K.G. All authors have read and agreed to the published version of the manuscript.

Funding: This research was funded by National Natural Science Foundation of China (No. 51978482).

Data Availability Statement: Not applicable.

Conflicts of Interest: The authors declare no conflict of interest.

\section{Nomenclature}

$\begin{array}{ll}\text { NCEDD } & \text { near-zero carbon emission demonstration district } \\ \text { GHGs } & \text { greenhouse gas emissions } \\ \text { CCS } & \text { carbon capture and storage } \\ \text { LNG } & \text { liquefied natural gas } \\ \text { CFD } & \text { computational fluid dynamics } \\ \text { GDP } & \text { gross domestic product } \\ \text { LED } & \text { light emitting diode } \\ \text { VOC } & \text { volatile organic compounds } \\ \text { EER } & \text { energy efficiency ratio } \\ \text { COP } & \text { coefficient of performance } \\ \text { IPLV(C) } & \text { integrated part load value (cooling) } \\ \text { D } & \text { nominal evaporation of boiler, } t / h \\ \text { Q } & \text { nominal heating output of boiler, MW } \\ \text { PV } & \text { photovoltaics } \\ \text { BIPV } & \text { building integrated photovoltaics } \\ \text { EV } & \text { electric vehicle } \\ \text { AC } & \text { alternating current } \\ \text { EES } & \text { electrical energy storage } \\ \text { TES } & \text { thermal energy storage } \\ \text { CAES } & \text { compressed air energy storage } \\ \text { Tce } & \text { ton of standard coal equivalent } \\ \text { kgce } & \text { kilogram of standard coal equivalent } \\ \text { CNY } & \text { Chinese Yuan }\end{array}$




\section{References}

1. United Nations. The Paris Agreement. 2015. Available online: https://www.un.org/ga/search/view_doc.asp?symbol=FCCC/ CP/2015/L.9/Rev.1 (accessed on 21 January 2021).

2. Zheng, J. Analysis on the Impact of EU Green New Deal and Green Agreement. Environ. Sustain. Dev. $2020,2,40-42$.

3. Tang, Y.; Chen, W. The Impact of Biden's Climate and Energy Policy Proposition on China and its Suggestions and Countermeasures. World Sci.-Tech. RED 2021, 43, 605-615.

4. Li, H.; Cui, G. Main Points and Enlightenment of Japan's Green Growth Strategy. China Electr. Equip. Ind. 2021, 6, 52-55.

5. Xi, J. Speech at the General Debate of the 75th United Nations General Assembly. China Daily, 24 September 2020. Available online: http:/ / www.chinadaily.com.cn/a/202009/24/WS5f6c08aca31024ad0ba7b776.html (accessed on 21 January 2021).

6. China CCTV. The Central Committee of the Communist Party of China and the State Council issued the "Opinions on the Complete, Accurate and Comprehensive Implementation of the New Development Concept to Achieve Carbon Peak and Carbon Neutrality". Shanghai Energy Conserv. 2021, 10, 1054.

7. Wang, Z.; Xue, L. The Release of "Carbon Peak Action Plan by 2030". Resour. Guide 2021, 11, 7.

8. He, C.; Jiang, K.; Chen, S.; Jiang, W.; Liu, J. Zero $\mathrm{CO}_{2}$ Emissions for an Ultra-Large City by 2050: Case Study for Beijing. Curr. Opin. Environ. Sustain. 2019, 36, 141-155. [CrossRef]

9. IPCC. Special Report on Global Warming of $1.5^{\circ} \mathrm{C}$; Cambridge University Press: Cambridge, UK, 2018.

10. Deng, X.; Xie, J.; Teng, F. What is Carbon Neutrality. Clim. Chang. Res. 2021, 1, 107-113.

11. Cai, B.; Li, W.; Dhakal, S.; Wang, J. Source Data Supported High Resolution Carbon Emissions Inventory for Urban Areas of the Beijing-Tianjin-Hebei Region: Spatial Patterns, Decomposition and Policy Implications. J. Environ. Manag. 2017, 206, 786-799. [CrossRef]

12. Li, Y.; Sun, L.; Zhuang, G. Analysis on the Connotation and Construction Path of Near-Zero Carbon Emission Demonstration Zone. Bus. Econ. 2017, 36, 21-25.

13. Liu, C. China Demonstration Project Construction Path and Supporting Measures in Near-zero Carbon Emission Zone. China Econ. Trade Guide 2017, 36, 58-60.

14. Long, W. Demand-Side Urban Energy Planning. HVEAC 2015, 45, 60-66.

15. Long, W.; Liu, K. Some Key Points in Urban Demand Side Energy Planning. HVEAC 2017, 47, 2-9.

16. Long, W. Demand Side Energy Planning of Green Industry Park. Shanghai Energy Conserv. 2016, 10, 533-539.

17. Long, W. Demand-Side Energy Planning Complied with Supply Side Structural Reform-Preface of Book "Demand-Side Community Energy Planning and Energy Micro-Net Technologies". HVEAC 2016, 46, 135-138.

18. Jelić, M.; Batić, M.; Tomašević, N. Demand-Side Flexibility Impact on Prosumer Energy System Planning. Energies 2021, 14, 7076. [CrossRef]

19. Wang, J.; Zeng, P.; Liu, J.; Li, Y. Coordinated Planning of Multi-Energy Systems Considering Demand Side Response. In Energy Reports, Proceedings of the 2020 7th International Conference on Power and Energy Systems Engineering (CPESE 2020), Fukuoka, Japan, 26-29 September 2020; Elsevier: Fukuoka, Japan, 2020.

20. Yu, H.; Huang, Z.; Pan, Y.; Chen, W.; Jing, R.; Li, Y.; Li, Y.; Lin, M.; Liu, H.; Liu, J.; et al. Guidelines for the Implementation of Urban Demand Side Energy Planning; China Construction Industry Press: Beijing, China, 2018; p. 375. Available online: http:/ /ss.zhizhen.com/detail_38502727e7500f266958a49170b691e38c0b18b32cfbbeb31921b0a3ea25510134114c969f2eae5 cea2a197fb58a956c1ecadaf343b123bdcbb66c56596b1631d3553196fe37f46855337573c23a06c5? (accessed on 28 November 2021).

21. Khalilpour, K.R. The Transition from X\% to $100 \%$ Renewable Future: Perspective and Prospective, Polygeneration with Polystorage for Chemical and Energy Hubs. Acad. Press 2019, 513-549. Available online: http://ss.zhizhen.com/detail_38502727 e7500f265bcd780c2f14aa8e2db5e5bc5fdc4f821921b0a3ea255101c944b624736f9e85f6b33ab1fdc5048fccc22aa85d4f7f2889125aed9 05f86484f16e318dea09d1ddf7462043f5301cf? (accessed on 28 November 2021).

22. Dobbelsteen, A.; Roggema, R.; Tillie, N.; Broersma, S.; Fremouw, M.; Martin, C.L. Urban Energy Transition; Elsevier: Amsterdam, The Netherlands. [CrossRef]

23. Shenzhen Academy of Building Research (Shenzhen, China). Special Energy Plan for Ya'an Green Ecological City. 2013, unpublished report. Available online: http://www.upssz.net.cn/newsinfo_803_997.html (accessed on 28 November 2021).

24. Cheng, L.; Zhang, J.; Huang, R.; Wang, C.; Tian, H. Case Analysis of Multi-Scenario Planning Based on Multi-Energy Complementation for Integrated Energy System. Electr. Power Autom. Equip. 2017, 37, 282-287.

25. Tang, M.; Xu, Z. Taking the Energy Planning of the Central District of Lingui New District in Guilin as an Example Discuss the Main Route of Demand Side Energy Planning. In Proceedings of the 2017 Annual Conference of Shanghai Institute of Refrigeration, Shanghai, China, 18 December 2017; China Academic Journal Electronic Publishing House: Shanghai, China, 2017.

26. Tianjin Architectural Design Institute (Tianjin, China). Energy Planning of Tianjin Health Industry Park University of Traditional Chinese Medicine. 2019, unpublished work.

27. Zhejiang Zheneng Energy Service (Zhejiang, China); Tongji Architectural Design Group (Shanghai, China). Integrated Energy Planning for Xiangbao District in Ningbo. 2018, unpublished work.

28. Renewable Energy Law of the People's Republic of China. 2006. Available online: http://bfqk.5read.com/pdf/67/\%E4\%B8 $\%$ AD $\%$ E5\%9B\%BD $\%$ E3\%80\%8A\%E5\%8F\%AF\%E5\%86\%8D\%E7\%94\%9F\%E8\%83\%BD \%E6\%BA\%90\%E6\%B3\%95\%E3\%80\% 8B\%E8\%BF\%91\%E6\%97\%A5\%E5\%87\%BA\%E5\%8F\%B0.pdf (accessed on 28 November 2021). 
29. Zhou, Z.; Wang, L.; Lin, A.; Zhang, M.; Niu, Z. Innovative Trend Analysis of Solar Radiation in China during 1962-2015. Renew. Energy 2017, 119, 675-689. [CrossRef]

30. Zhang, Y.; Ren, J.; Pu, Y.; Wang, P. Solar Energy Potential Assessment: A Framework to Integrate Geographic, Technological, and Economic Indices for a Potential Analysis. Renew. Energy 2019, 149, 577-586. [CrossRef]

31. Wang, Q.; Kwan, M.-P.; Fan, J.; Zhou, K.; Wang, Y.-F. A Study on the Spatial Distribution of the Renewable Energy Industries in China and Their Driving Factors. Renew. Energy 2019, 139, 161-175. [CrossRef]

32. Rocky Mountain Institute; National Center for Climate Change Strategy Research and International Cooperation (Beijing, China). Construction Planning and International Cooperation Project Report of Ningbo Meishan Near-Zero Carbon Emission Demonstration Zone. 2019, unpublished work.

33. Zhang, C.; Su, B.; Zhou, K.; Yang, S. Decomposition Analysis of China's CO 2 Emissions (2000-2016) and Scenario Analysis of Its Carbon Intensity Targets in 2020 and 2030. Sci. Total Environ. 2019, 668, 432-442. [CrossRef]

34. China National Standardization Committee. Technical Standard for Nearly Zero Energy Buildings GB/T 51350-2019; China Construction Industry Press: Beijing, China, 2019.

35. Development and Reform Commission of Zhejiang Province. The 13th Five-Year Plan for Low-Carbon Development in Zhejiang Province. 2016. Available online: http://www.zj.gov.cn/art/2016/5/20/art_1229540818_4666989.html (accessed on 28 November 2021).

36. The General Office of the People's Government of Zhejiang Province. Action Plan for Building a National Clean Energy Demonstration Province in Zhejiang Province (2018-2020). Available online: http:/ /www.zj.gov.cn/art/2018/9/25/art_12290193 65_61718.html (accessed on 28 November 2021).

37. He, Z. The Start of Construction of Hebei Beidaihe Ubiquitous Power Internet of Things in Comprehensive Demonstration Park Project. National Grid News, 14 November 2019.

38. Kang, W.; Wu, Y. Hebei Zhengding Builds County-Level Energy Internet Comprehensive Demonstration Zone. National Grid News, 8 August 2019.

39. Wang, D. Preliminary Study on Henan Electric Power Lankao Energy Internet Comprehensive Demonstration Project. China Electric Power News, 11 November 2019.

40. Revesz, A.; Jones, P.; Dunham, C.; Davies, G.; Marques, C.; Matabuena, R.; Scott, J.; Maidment, G. Developing Novel 5th Generation District Energy Networks. Energy 2020, 201, 117-389. [CrossRef] 